\title{
Carboniferous petroleum systems around the Mid North Sea High, UK.
}

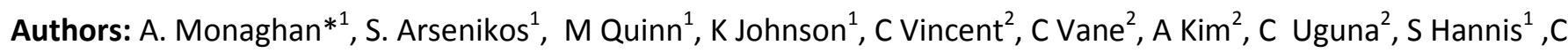
Gent $^{2}$, D Millward ${ }^{1}$, T Kearsey ${ }^{1}$, P Williamson ${ }^{2}$.

*Lead author-als@bgs.ac.uk

${ }^{1}$ British Geological Survey, The Lyell Centre, Research Avenue South, Edinburgh, EH14 4AP, UK

${ }^{2}$ British Geological Survey, Nicker Hill, Keyworth, NG12 5GG, UK

Keywords: Visean, Namurian, source, reservoir, seal, trap, gas, oil

Highlights:

- Extensive mapping of variably mature, dominantly gas-prone Visean-Namurian source rocks

- Evidence for widespread Visean-Namurian petroleum system elements

- Modelling indicates Palaeozoic and Cenozoic oil and gas generation from Carboniferous basins

- Kilometres thick succession offers intraformational reservoirs, seals and structural traps

\begin{abstract}
The existence of an extensive, prospective Visean-Namurian Carboniferous petroleum system in and around the hitherto under-explored Mid North Sea High is documented. Evidence is drawn from integrated analysis of over 50,000 line kilometres of seismic data and well data, together with regional source rock screening, reservoir analysis and basin modelling.
\end{abstract}

Visean-Namurian marine and non-marine mudstones and coal source rocks are interbedded within fluvial and marine reservoir sandstones within a stacked succession up to $5 \mathrm{~km}$ thick. Source rocks are dominantly gas-prone with oil-prone intervals, and have reached oil to gas maturity levels dependent on location. Burial/thermal history modelling indicates a kitchen area on the southern margin of the Mid North Sea High with northwest and northeastwards migration of gas and oil during Mesozoic and Cenozoic times. A variety of structural and stratigraphic traps are possible, including intraformational Carboniferous traps, with a regional seal at Permian (Zechstein) level. Synthesis of many previously unpublished datasets demonstrates the Visean-Namurian play south of the Mid North Sea High as part of an extensive petroleum system from the East Irish Sea, across onshore to offshore UK and into The Netherlands sector of the North Sea. The purpose of this synthesis is to highlight future exploration opportunities beneath and northwards of the productive Westphalian Southern North Sea gas basin, and 
to begin to de-risk the petroleum systems that are exemplified by the lower Carboniferous Breagh Field in a frontier area of the mature North Sea province.

\section{Introduction}

For both maximum economic recovery and security of energy supply, the UK Government and Oil and Gas Authority advocate extending the life of the mature North Sea province. This paper synthesises regional datasets in a previously under-explored area to highlight a petroleum system beneath and northwards of the existing, world-class Southern North Sea gas province, potentially extending the life of the mature UK North Sea province into a frontier area.

The Breagh Field (blocks 42/12a, 42/13a; Figures 1, 2), with total recoverable reserves estimated at 19.8 billion cubic metres (699 billion cubic feet) gas (DEA Group, 2015), proves a working petroleum system in older Visean-Namurian age strata than in the highly productive Westphalian strata predominant in the Southern North Sea gas province (Figures 1, 2; Cameron et al., 2005; Kombrink et al., 2010; Symonds, 2015; Symonds et al., 2015; Underhill, 2003). The spatially extensive Visean-Namurian succession subcrops at the base Permian unconformity on the southern margin of the 'Mid North Sea High' (Collinson, 2005) and has been seismically interpreted in Quadrants 29, 37, 38 and 39 of the UK Continental Shelf (UKCS) (Hay et al., 2005; Milton-Worssell et al., 2010), leading to suggestions of a potentially prospective petroleum system in these lower-middle parts of the Carboniferous succession (e.g. MiltonWorssell et al., 2010). Lessons learned from exploration and production within the Southern North Sea WestphalianPermian play, such as the challenges of seismic interpretation beneath Zechstein evaporites, complex structure and correlation of sandstones lacking biostratigraphic control (Besly, 2005; Cameron et al., 2005), combined with sparse datasets and lack of regional geological knowledge, had led to Visean-Namurian Carboniferous petroleum systems being viewed as frontier and risky (e.g. Besly, in press).

Consultation following a major review of the UK oil and gas industry by Wood (2014) identified certain Devonian and Carboniferous potential plays of the UKCS as of top significance for building regional digital datasets and stimulating exploration, to maximise economic recovery. Together with the UK Government-funded seismic survey of the Mid North Sea High (MNSH) released in 2016 and the UK Government $29^{\text {th }}$ Offshore Licensing Round, the $21^{\text {st }}$ Century 
Exploration Roadmap (21CXRM) Palaeozoic Project (2014-2016) contributed to increased exploration activity of the 'frontier' MNSH region. This paper is a regional scale synthesis of the prospective Visean-Namurian petroleum systems evidenced in detail in the 21CXRM Palaeozoic project datasets and explanatory reports released in $2017^{*}$. This work incorporates released and unreleased data, including thousands of previously unpublished biostratigraphic, geochemical and core sample analyses, to begin to challenge some of the 'founding myths' (Besly, in press) of Carboniferous prospectivity.

The study area covers Quadrants 25-44 of the UKCS (Figures 2, 3), encompassing the geographical area termed the 'Mid North Sea High' that separates the Southern and Northern Permian basins. The 'MNSH' is loosely defined and of varying extent within published maps and literature. The term is best applied at Permian level as the area includes a number of underlying Devonian-Carboniferous basins. A Carboniferous relative high is present under the southern part of Quadrant 26, Quadrants 27, 28 and northern parts of Quadrants 34, 35, 36 (e.g. Arsenikos et al., 2015, in press; Figures 2,4), though the paucity and quality of data makes definition of its full extent difficult. Within this paper the term 'Mid North Sea High' is used in its loose geographical sense, with study sub-areas referred to as shown on Figure 3. Western European stage and substage timescale names are used, with early/lower and late/upper Carboniferous used informally. 


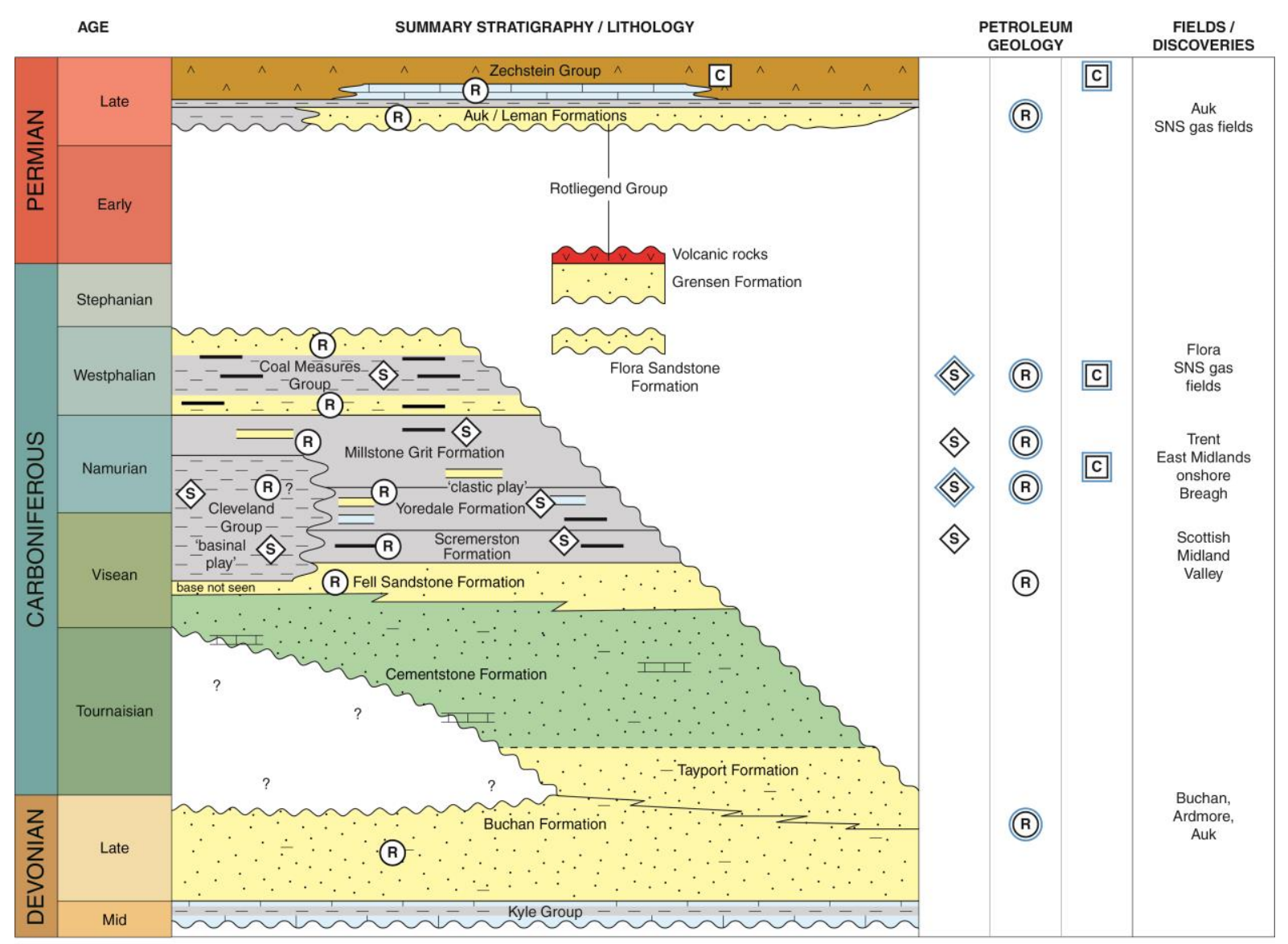

(s) Source rock inferred, double edged where proved in fields

(B) Reservoir rock interval, double edged where proved in fields

C Cap (or seal) rock interval, double edged where proved in fields

Figure 1 Summary of upper Devonian, Carboniferous and Permian stratigraphy with potential source, reservoir and seal rocks indicated along with existing hydrocarbon fields. Note that the Cleveland Group includes the Upper Bowland Shale. The stratigraphy found in the north and east of the study area is broadly on the right hand side, the stratigraphy in the south and west of the study area is broadly on the left hand side.

\subsection{REGIONAL EVIDENCE FOR A VISEAN-NAMURIAN PETROLEUM SYSTEM AND SYSTEM ELEMENTS}

Visean and Namurian oil and gas fields, discoveries and shows in Quadrants 25-44 of the UKCS are dominantly located on the southern margin of the MNSH and are part of an extensive, connected swathe of hydrocarbon-related finds of a similar age (Figures 2, 3). They link up eastwards into the Netherlands sector, and extend westwards across the UK (incorporating onshore oil and gas fields of the East Midlands and Cleveland Basin and prospective onshore UK shale gas resources) and into the Carboniferous-sourced, Triassic-reservoired fields of the East Irish Sea (Figure 2). Situated north of the Westphalian gas basin, the data collation from offshore well reports (Vane et al., 
2015) summarised in Figure 2 presents evidence for a Visean-Namurian petroleum system and/or Visean-Namurian petroleum system elements.

The East Midlands oil fields (Figures 1 and 2) are largely sourced from Namurian basinal shales (DECC, 2013; Kombrink et al., 2010; Pharaoh et al., 2011; Pletsch et al., 2010), with Namurian and Westphalian channel-sandstone reservoirs, and have been producing for many years. Several Namurian-sourced gas fields occur in the Cleveland Basin in Permian reservoirs (DECC, 2013; Pletsch et al., 2010), onshore from Quadrant 41 (Figure 2). Significant onshore shale gas resources have been estimated within the Namurian basinal shales (Andrews, 2014) and these rocks also form the source for the East Irish Sea oil and gas fields (Armstrong et al., 1997). Gerling et al. (1999) highlighted the likely contribution of a mature Namurian basinal source rock in addition to Westphalian Coal Measures to gas fields of the Southern North Sea.

A working petroleum system also exists to the north of the Mid North Sea High as evidenced by Carboniferous oil and gas shows in the Forth Approaches (Quadrant 26), together with shows and the previous Midlothian, D'ArcyCousland fields in the Midland Valley of Scotland (Figure 2). Oil and gas production in the Midland Valley of Scotland was sourced from, and trapped in, lower Carboniferous strata (Hallett et al., 1985; Underhill et al., 2008). Prospective shale gas and shale oil resources have also been mapped within the Visean and Namurian succession (Monaghan, 2014).

The hydrocarbon shows and fields within thick Visean and Namurian lacustrine, fluvio-deltaic and marine successions (Figure 2; Monaghan et al., 2015; Vane et al., 2015) highlight that source, reservoir and seal rocks exist within both structural and stratigraphic traps, as well as being potential source rocks for younger Westphalian and Permian reservoirs. Data summarised in this paper provides further evidence for both a prospective Visean-Namurian petroleum system and for Visean-Namurian petroleum system elements across Quadrants 25-44. 


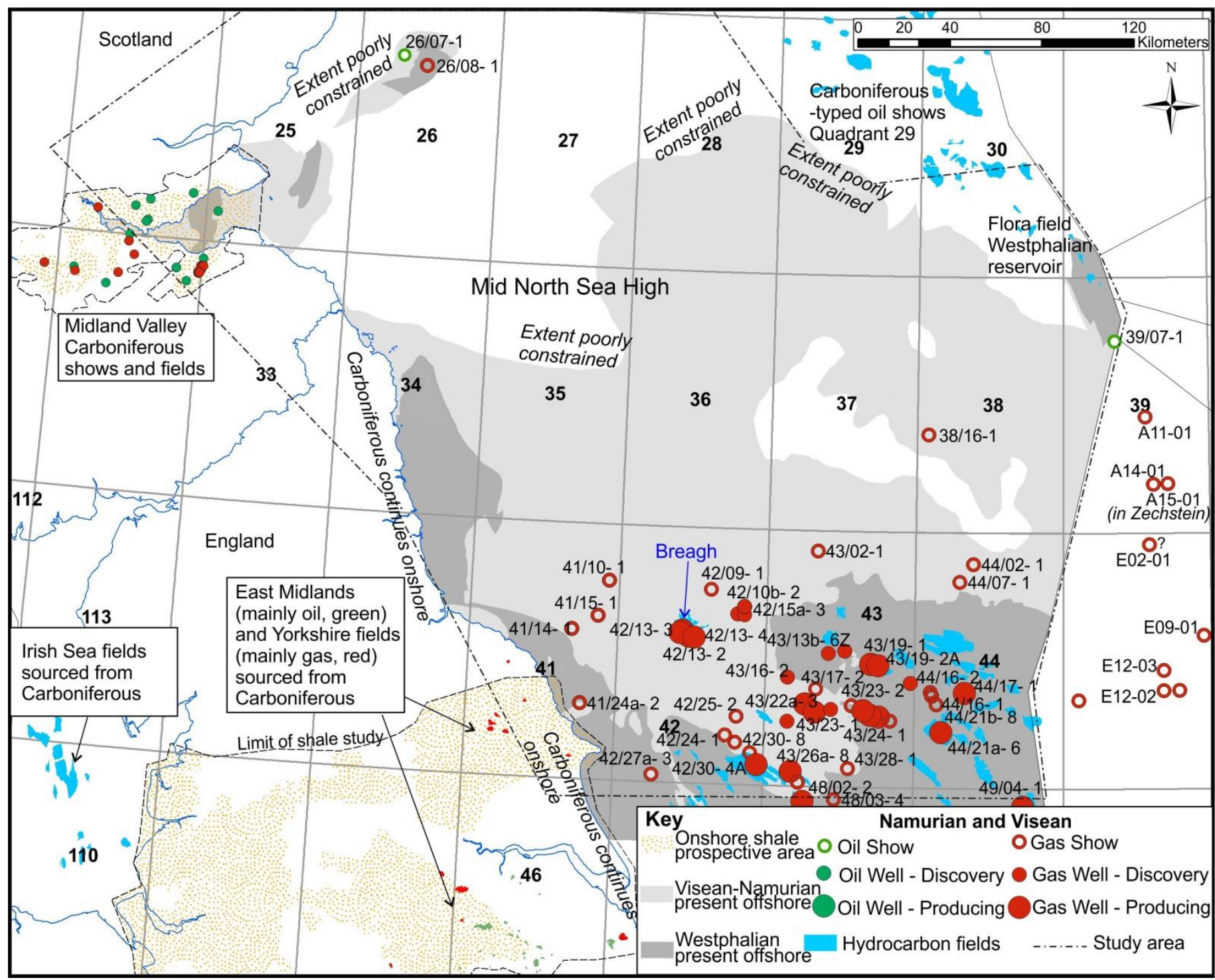

Figure 2 Map of Visean-Namurian shows, discoveries and fields across Quadrants 25-44 from a review of well reports (Vane et al., 2015). Also includes Visean-Namurian gas shows in The Netherlands sector from ter Borgh et al. (in press a), onshore oil and gas fields of the East Midlands and Yorkshire (Pletsch et al., 2010), Namurian shale gas resources (Andrews, 2013), Irish Sea fields, and Midland Valley of Scotland oil and gas shows and shale resources (Monaghan, 2014). 


\section{Datasets and methodology}

This paper synthesizes information from a set of nine detailed, evidence-based reports that were peer-reviewed by industry and Oil and Gas Authority experts during the 21CXRM Palaeozoic Project. An interpretation of key stratigraphic boundaries and faults from over 50,000 kilometres of regional 2D long-offset seismic data and selected 3D surveys (Figure 3) was presented by Arsenikos et al. (2015, in press). These were tied to re-interpreted well data in order to map an extensive ViseanNamurian aged basin fill of fluvio-deltaic, lacustrine and marine mudstones, siltstones, sandstones, limestones and coals (Kearsey et al., 2015, in press). Well data are sparse, with many wells terminating just into the Carboniferous succession. Gravity and magnetic studies constrained basin geometries further in areas of wide seismic data spacing, and delineated areas of granitic and other igneous intrusions (Arsenikos et al., in press; Kimbell and Williamson, 2015).

Rock-Eval and vitrinite reflectance source rock data from variable vintage legacy well reports, papers and donated datasets were tabulated, and combined with 150 new BGS analyses, to result in more than 2500 rows of data for upper Palaeozoic samples from 76 wells (Figure 4; Vane et al., 2015). Regional screening was undertaken on a well by well basis to examine source rock quality, remaining hydrocarbon generation potential, maturity etc. and linked to text descriptions of kerogen type and geochemical typing studies (Vane et al., 2015). However, given the spatial and downhole sparsity of sample data, 31 well logs were also petrophysically analysed to offer a more continuous depth range output than the geochemical sample analyses (Gent, 2015). This provided an indication of the percentage of shale and total organic content with depth (Figure 3). Source rock, seismic and well interpretations were combined in a thermal and burial basin history modelling study using BasinMod $^{\mathrm{TM}}$ 1D and 3D (Vincent, 2015). 
Porosity and permeability data were tabulated from legacy well reports of tests on core samples from over 100 wells (Hannis, 2015). To further characterise Carboniferous and Devonian reservoir intervals, the core data were used to calibrate continuous (along borehole) petrophysical well log analyses to calculate net to gross (porosity $>5 \%$, clay volume $<50 \%$ cut off), porosity and permeability (permeability transforms were calculated on a well-by- well and formation-by-formation basis using the Robust Fit regression method in $\mathrm{IP}^{\mathrm{TM}}$ ) of potential reservoir intervals (Hannis, 2015; Figure 3). The various datasets were integrated and synthesised to a petroleum system analysis (Monaghan et al., 2015), which is summarised in this paper. The methodology focussed on gathering of basic geological datasets and regionally-consistent interpretations to enable future block-scale studies, rather than a play fairway or common risk segment mapping approach.

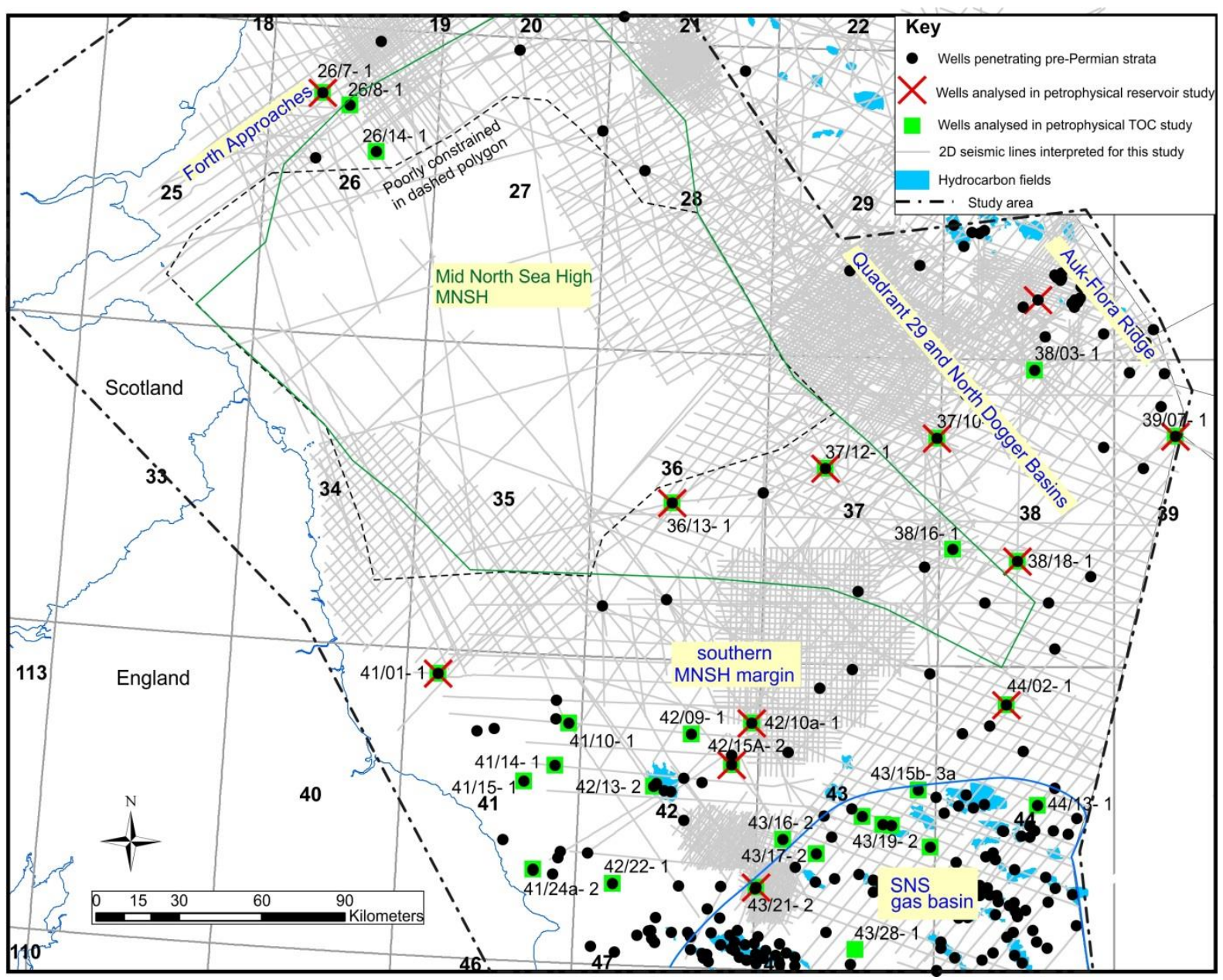

Figure 3 Data coverage of 2D seismic datasets and wells penetrating pre-Permian strata, together with the study areas discussed in the text. 3D seismic data used in Quadrants 28, 
29,30 , northern $37-39,42$ is not shown. Note that the study used released and unreleased seismic data prior to the completion of the 2016 Government seismic data (not shown) over the Mid North Sea High. Wells used in petrophysical studies of Total Organic Carbon (Gent, 2015) and porosity and permeability (Hannis, 2015) are highlighted. The interpretational confidence is extremely variable, relating to both data density and data vintage and quality. Seismic data were chosen for their penetration and reflectivity of Palaeozoic intervals, however variable data quality impacts confidence e.g. beneath areas of complex halokinesis (Arsenikos et al. 2015, in press). The most sparse data coverage and lowest confidence is over the dashed area of the MNSH, whereas the densest data coverage and highest confidence is for the southern MNSH margin (Figure 3).

\section{Overview of Palaeozoic petroleum systems in and}

\section{around the Mid North Sea High}

\subsection{OVERVIEW OF CARBONIFEROUS BASINS}

A range of Carboniferous basin orientations, depths and thicknesses have been mapped in and around the MNSH, strongly influencing basin fill, basin history and potential prospectivity (Figure 4; Arsenikos et al., 2015, in press; Vincent, 2015). In southern parts of Quadrants 37 and 38, Carboniferous units onlap the southwestern margin of the Dogger Granite High and pass westwards and southwards to a series of basins and local highs (Figure 4). The Breagh Field and Crosgan discovery are located on one of these highs (Figure 4). In Quadrants 43-44 the mapped top Scremerston Formation dips steeply to $5 \mathrm{~km}$ depth, beneath the younger Carboniferous strata of the Silverpit basin (Figure 4). Recent studies by Rodriguez et al. (2014), Parsons (2015) and Patruno et al. (2017) have also considered the hydrocarbon potential of the lower Carboniferous play around parts of this southern margin of the Mid North Sea High. Farther to the south and west towards the 
onshore Cleveland Basin (Quadrants 41 and 42) insufficient resolution of seismic data at Carboniferous levels precluded interpretation. Seismic interpretation further to the north in Quadrants 34-36 delineated the offshore extension of the Northumberland Trough and a series of NW-trending faults (Figure 4), although this area is very poorly constrained by well ties (see Arsenikos et al., 2015, in press).

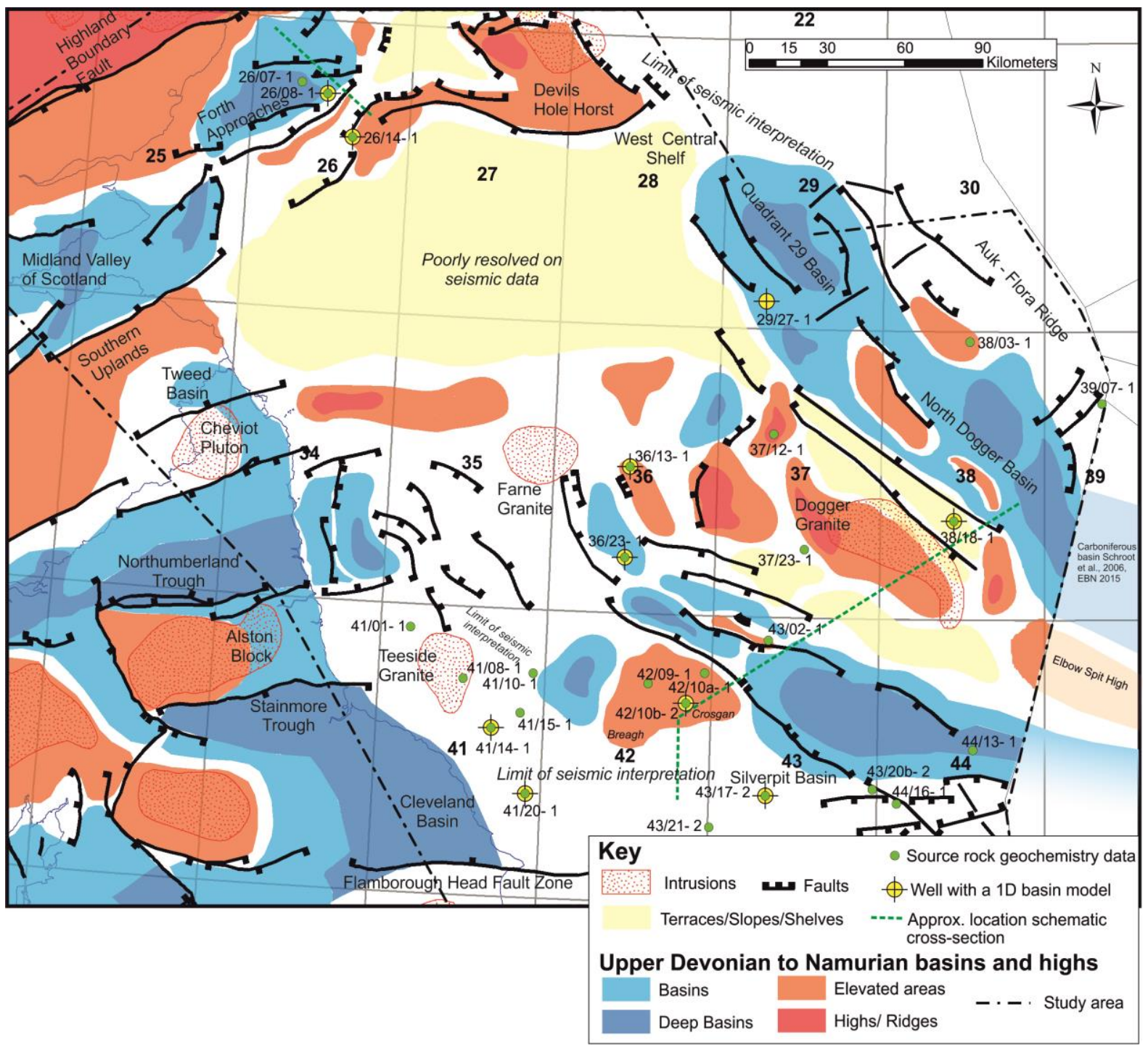

Figure 4 Summary structural overview of the Devonian and Carboniferous basins and highs discussed in the text. The location of wells studied for source rock geochemistry (Vane et al., 2015) and basin modelling (Vincent, 2015) are highlighted.

A lower Carboniferous 'Quadrant 29' basin, unproved by well penetrations, was mapped from seismic data in the southern part of Quadrant 29 by Hay et al. (2005). Seismic and gravity data 
interpretations by Milton-Worssell et al. (2010) illustrated the continuation of this basin to the south-east into Quadrants 37, 38 and 39, south-west of the Auk-Flora ridge. Situated outside the area of Jurassic source rock, Hay et al. (2005) noted the correlation between the occurrence of gas chimneys and shallow gas in southern Quadrant 29 within the mapped basin, and suggested a deep thermogenic, Carboniferous source for the gas. Using independent well log and stratigraphic reinterpretations and an extensive seismic dataset, the extent of the Quadrant 29 and North Dogger Devonian and Carboniferous basins have been further delineated as significant Palaeozoic structural elements (Figure 4: Arsenikos et al., 2015, in press). The structural configuration continues in The Netherlands sector where Carboniferous basins have been mapped to the north-east and southwest of the Elbow Spit High (EBN 2015 a,b; ter Borgh et al., in press a,b).

To the north of the Mid North Sea High, the Forth Approaches Basin is mapped as a complex halfgraben structure with Carboniferous strata reaching depths of around $3-4 \mathrm{~km}$. Together with a Carboniferous basin in Quadrant 25, these structures form an en-echelon continuation of the onshore Midland Valley of Scotland (Figure 4; Arsenikos et al., 2015, in press).

A key finding of the regional seismic mapping is the extent of Visean (Holkerian-Asbian) coal and mudstone source rocks of the laterally equivalent of the Scremerston, Firth Coal formations and Cleveland Group, at depths of around 3-5 km. They were found to extend from the southern Mid North Sea High and Silverpit Basin, to the North Dogger and Quadrant 29 basins, and within the Forth Approaches Basin (grey shaded extent of Visean-Namurian succession on Figure 2; Arsenikos et al., 2015, in press.

\subsection{PALAEOZOIC PETROLEUM SYSTEM ELEMENTS}

A number of Palaeozoic petroleum systems or system elements can be defined around the Mid North Sea High (Quadrants 25-44) including the productive Westphalian and Permian plays of the Southern North Sea (Figure 5). This paper highlights interpretations of a Visean-Namurian 'clastic 
play' and a coeval, siltstone-mudstone, marine-dominated 'basinal play' (Figures 1, 5, 6). The clastic play comprises fluvio-deltaic, lacustrine and periodic shallow marine environments within the Fell Sandstone, Scremerston, Yoredale and Millstone Grit formations (proved in Quadrants 26, 29, 36-39 and northern parts of blocks of Quadrants 41-44), and the basinal play the Cleveland Group including the Upper Bowland Shale (southern parts of Quadrants 41-44; Figures 1, 5, 6). The spatial extents of the kilometres-thick successions are controlled by both depositional facies, as highlighted in palaeogeographic reconstructions from the Arundian to Pendleian (Kearsey et al., 2015, in press), and erosion at the latest Carboniferous-early Permian Variscan Unconformity (Figure 5).

Similar to the Westphalian Coal Measures, Visean-Namurian strata (Fell, Scremerston, Yoredale, Millstone Grit formations and the basinal Cleveland Group units) are commonly heterolithic and the younger units are cyclical, responding to variations in sea level, tectonics and sediment supply. Mudstone, carbonaceous mudstone, coal, oil shale and bituminous limestone source rocks occur in close proximity to reservoir rocks - mainly coarse channel sandstones or estuarine and coastal sandstones. Intraformational seals could be provided by extensive mudstones.

An overview schematic cross-section from the south to the east of the Mid North Sea High (Figure 5) highlights the vertically stacked and laterally equivalent Palaeozoic petroleum system elements. Intraformational Carboniferous traps and seals could be extremely important within the ViseanNamurian clastic and basinal plays. Structural and dip traps of faulted/folded Carboniferous strata against the base Permian unconformity and seal (Zechstein evaporites) are the primary trap/seal mechanism envisaged. High quality Permian reservoirs (e.g. the Auk and Leman sandstones) are also located beneath the Zechstein seal in some parts of the study area. 


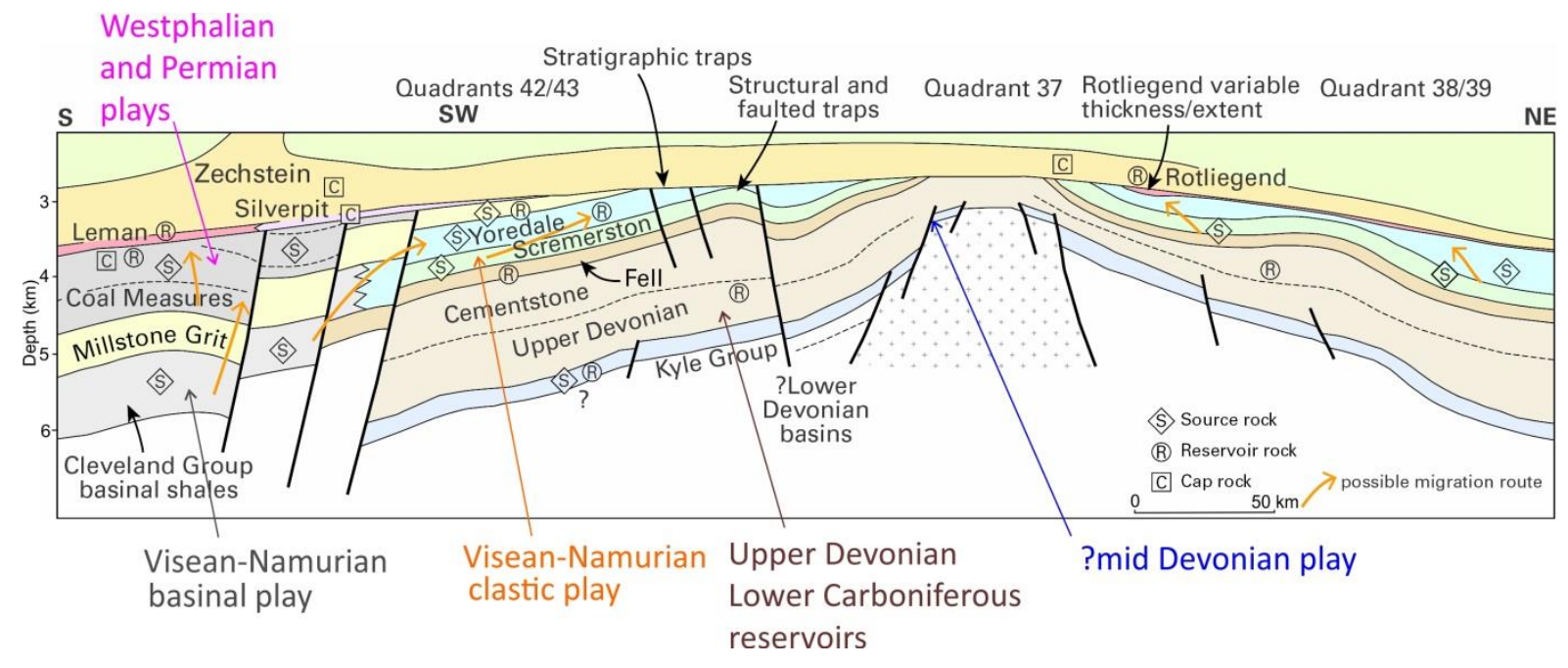

Figure 5 Overview schematic cross-section of Visean-Namurian plays and other Palaeozoic petroleum system elements from Quadrants 38-43, the approximate line location is shown on Figure 4.

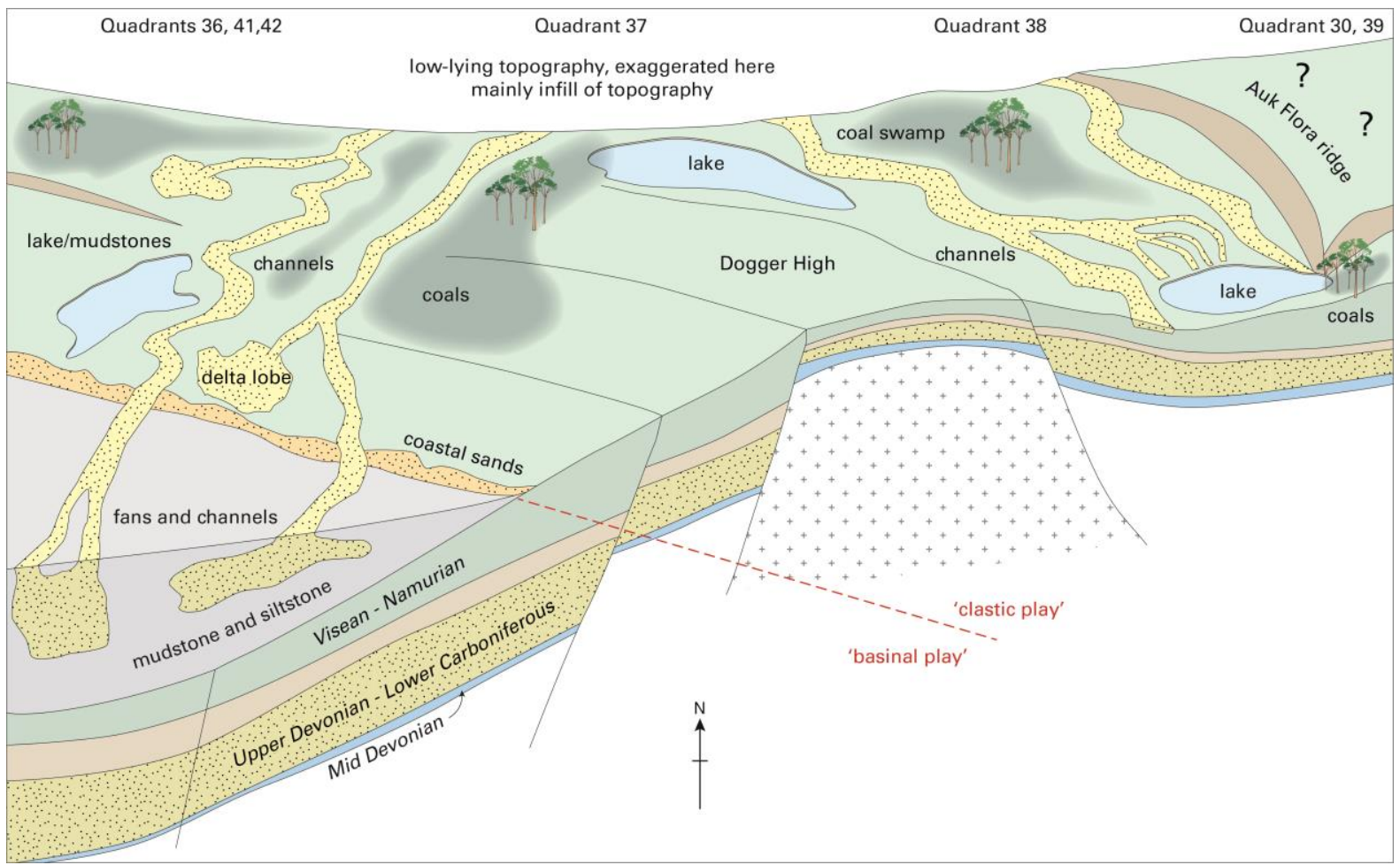

Figure 6 3D schematic block diagram of the generalised structure and lowstand depositional environments in the Scremerston/Yoredale formations across Quadrants 3544. The topography in the diagram is exaggerated to highlight the features. In reality, sedimentation is interpreted to have kept pace with tectonism such that fault scarps would not likely have been exposed.. During highstands, marine incursions occurred across the fluvio-deltaic plain. 
The lower Carboniferous clastic play is also a key part of the structurally-controlled Palaeozoic petroleum system in the Forth Approaches, north of the MNSH. Coal, mudstone and thin oil-shale source rocks are present within the Visean Firth Coal/Scremerston Formation (Figure 7; see also Bruce and Stemmerik, 2003). Clastic reservoirs of mid-late Carboniferous or Rotliegend age and possible Zechstein carbonate reservoirs are capped by Zechstein evaporites, often strongly affected by halokinesis, which likely form an effective seal (Figure 7). Local intraformational mudstone seals within the Carboniferous are possible and were effective onshore in trapping hydrocarbons and form the Midlothian Field in the faulted D'Arcy-Cousland anticline (Hallett et al., 1985).

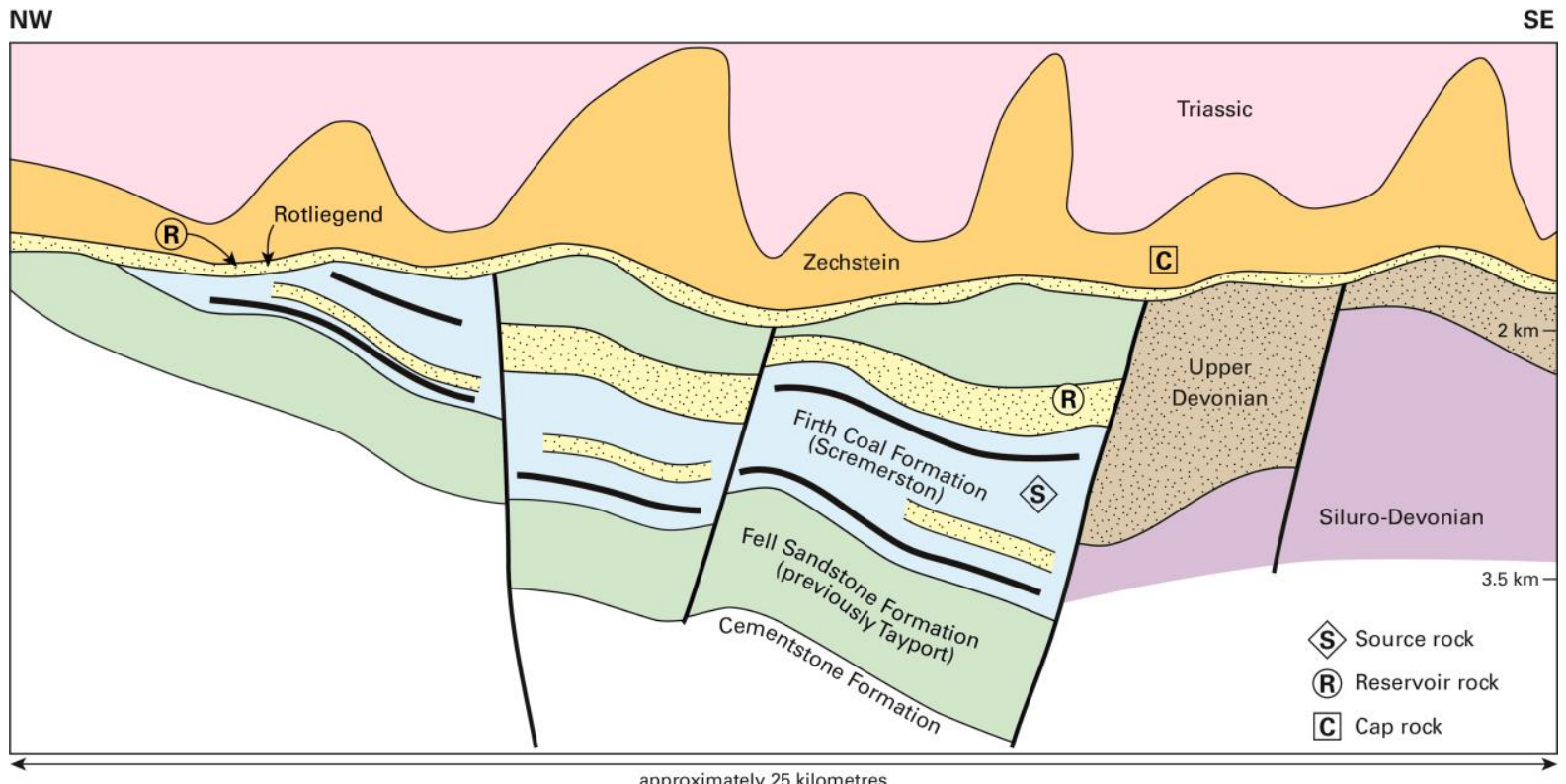

Figure 7 Summary schematic cross section of the Forth Approaches CarboniferousPermian petroleum system, the approximate line location is shown on Figure 4.

The evidence for prospective petroleum system elements sourced by, and within the ViseanNamurian succession follows a summary of the overlying Carboniferous (Westphalian) and Permian petroleum systems.

\subsubsection{Westphalian petroleum system of the Southern North Sea}

The Southern North Sea (SNS) gas fields form part of a major gas-producing Carboniferous and Permian petroleum province located to the south of the Mid North Sea High (Figures 1, 2, 3). They 
are located above and south of Visean-Namurian petroleum system elements and of relevance to them. SNS gas accumulations were sourced from Westphalian coals, with some possible contributions from Namurian marine shales (Gerling et al. 1999; Kombrink et al., 2010). Gas generation is thought to have been widespread until Mid-Jurassic times with renewed generation and migration during the Neogene (Pletsch, 2010). Migration is believed to be local, from coal source beds into sandstones. Long range northwards migration of Westphalian-sourced gas has previously been hypothesized, into Visean-Namurian reservoirs within Quadrant 42 (e.g. RWE Dea, 2011b). No geochemical typing data have been located and this paper describes mature Visean and Namurian source rocks, suggesting that long range migration of Westphalian-sourced gas is not required.

Fields with Westphalian sandstone reservoirs include Ketch, Schooner, Caister and Murdoch with an uppermost Namurian Millstone Grit reservoir in the Cavendish Field (Cameron et al., 2005; Kombrink et al., 2010).

Dip and fault closures adjacent to the base Permian unconformity and Permian seal rocks form a major trap type on NW-SE/WNW-ESE and NE-SW structural trends (Cameron et al., 2005; Fraser and Gawthorpe, 1990; Pletsch et al., 2010). Some intraformational Carboniferous sealing by mudstones has been documented e.g. in the Boulton field (Kombrink et al., 2010).

\subsubsection{Permian reservoirs and seals}

The Permian Rotliegend and Zechstein groups contain proved reservoir and seal intervals across the SNS, and are an important part of the petroleum system for Visean-Namurian sourced hydrocarbons. Permian age hydrocarbon fields lie predominantly within Rotliegend Group reservoirs, for example the Leman, Indefatigable and Ravenspurn fields of the Southern North Sea gas basin, as well as the Cygnus field (Breunese et al., 2010; Catto et al., 2017; Taggart, 2015; Underhill, 2003). In Quadrants 35-39, the Rotliegend Group is thin or absent across the MNSH dividing the Southern and Northern Permian Basins (e.g. Gast et al., 2010; Underhill, 2003). 
Gas discoveries (Ralph Cross, Westerdale) have also been made in onshore equivalents of the Zechstein Group Plattendolomit (Underhill, 2003) as well as offshore in the Plattendolomit (Wissey, Hewett fields; Peryt, 2010). Patruno et al. (2017) summarise the Zechstein reservoir potential of the MNSH area.

The regional top seal to Rotliegend and Carboniferous reservoirs is provided by Zechstein evaporites. Thicknesses of the evaporite facies can vary from less than $50 \mathrm{~m}$ to over $1500 \mathrm{~m}$, and is often highly variable due to halokinesis (Cameron et al., 1992a). Regional mapping indicates the thinnest Zechstein succession occurs in the southern parts of Quadrants 30, 31 and northern parts of Quadrants 38, 39 (see Monaghan et al., 2015 fig 19). The desert playa Silverpit Formation (Rotliegend Group) comprises shales and evaporites that act as a local seal in the Silverpit-Cleaver Bank area (Cameron et al., 1992b; Underhill, 2003).

\section{Visean-Namurian source rocks}

Within the lithologically mixed Visean-Namurian succession, source-rock potential is offered by common organic-rich mudstone and coal, and rarer oil-shale and bituminous limestone (Monaghan et al., 2015; Vane et al., 2015; Vincent, 2015). Vane et al. (2015) screened Rock-Eval sample data on a well-by-well basis to show that source-rock quality varied from poor to excellent, with the Scremerston, Yoredale, Millstone Grit formations, Cleveland Group and time-equivalent units (Figure 1) all exhibiting source rock potential. Most of the rocks examined were gas-prone, with some oilprone intervals. A summary of the variability in source rock properties by geographical area is given in sections 4.1-4.4.

Pseudo Van Krevelen plots show mixed Type I-IV kerogens, with dominant Type III (humic, vitrinite) (e.g. Figures $8 \mathrm{a}, 10)$, consistent with well reports of visually or geochemically analysed kerogens (e.g. Kaye, 1995; Sauer, 1993). Well report analyses of migrated hydrocarbons, shows and fluid inclusions 
highlight that a non-marine Carboniferous source is the most commonly geochemically-typed (e.g. Farris et al., 2012; Premier, 2008). A marine-typed Carboniferous source is also documented (e.g. Pittion 1981; summary in Vane et al., 2015). 


\begin{tabular}{|l|l|l|l|l|}
\hline Unit & $\begin{array}{l}\text { Number } \\
\text { of wells } \\
\text { used }\end{array}$ & $\begin{array}{l}\text { Average TOC for all } \\
\text { mudstone } \quad \begin{array}{l}\text { Fraction } \\
\text { intervals } \\
\text { (calculated wt \%) }\end{array}\end{array}$ & $\begin{array}{l}\text { of } \\
\text { TOC >1 wt \% }\end{array}$ & $\begin{array}{l}\text { werage thickness } \\
\text { (m) } \\
\text { of mudstone } \\
\text { with TOC > 1\% }\end{array}$ \\
\hline Coal Measures Group & 7 & $0.8-3.3$ & $0.08-0.61$ & 46.1 \\
\hline $\begin{array}{l}\text { Millstone Grit } \\
\text { Formation }\end{array}$ & 12 & $1.4-2.7$ & $0.01-0.71$ & 239.5 \\
\hline Yoredale Formation & 8 & $1.1-3.4$ & $0.37-0.74$ & 294.8 \\
\hline $\begin{array}{l}\text { Scremerston } \\
\text { Formation }\end{array}$ & 10 & $1.4-4.1$ & $0.20-0.65$ & 175.0 \\
\hline $\begin{array}{l}\text { Cleveland Group (incl. } \\
\text { Upper Bowland Shale) }\end{array}$ & 6 & $1.4-3.4$ & $0.40-0.98$ & 678.1 \\
\hline Upper Bowland Shale & 6 & $1.4-3.4$ & $0.64-0.93$ & 57.6 \\
\hline
\end{tabular}

Table 1. Summary of petrophysical log derived properties for Carboniferous source rock formations from Gent (2015). Note that in several wells total drilling depth (TD) was reached within the unit meaning average thickness values are underestimated. Coals were excluded from the analysis.

Continuous petrophysical log analysis of mudstone intervals using the Passey method (Passey et al., 1990) and calibrated to Rock-Eval data showed the highest percentage of calculated Total Organic Carbon $(\mathrm{TOC})>1 \%$ in the Cleveland Group, with broadly similar results for the Yoredale and Scremerston formations (Table 1; Gent, 2015).

The following sections provide more detail on the variability of spatially and temporally extensive source rock intervals within the Scremerston, Yoredale and Millstone Grit formations and Cleveland Group.

\subsection{SOUTH OF THE MID NORTH SEA HIGH}

Collinson et al. (1995) highlighted the dominantly gas-prone source rock potential of the Yoredale and Millstone Grit units in the north of Quadrants $41-43$ and in Namurian basinal mudstones, siltstones and marine bands in southern parts of Quadrants 41-43. Dolan and Associates (1994), Hay et al. (2005) and Parsons (2015) also consider the Scremerston Formation to be a coal-bearing, gasprone source rock interval in this area. 

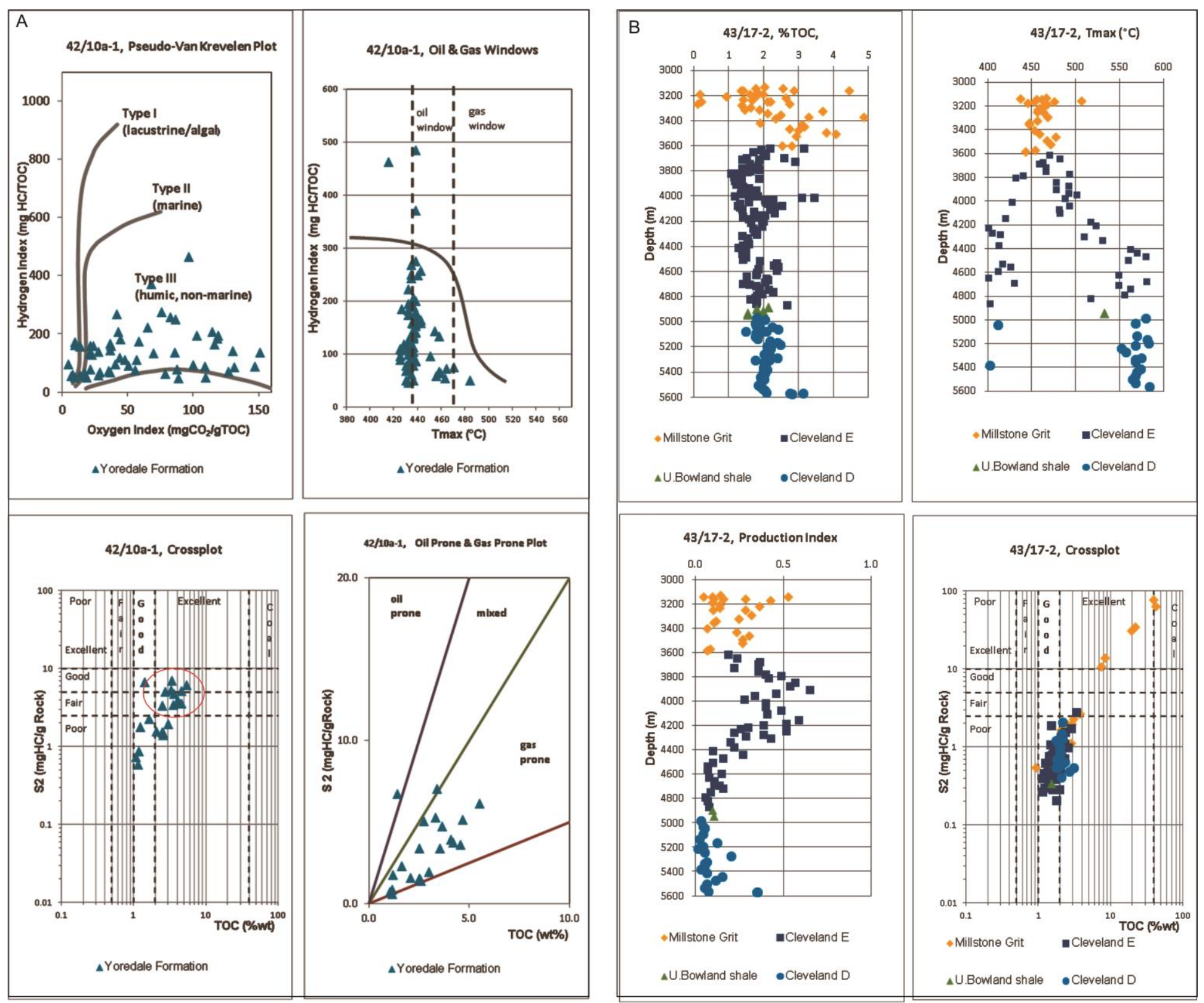
Figure 8 A selection of typical source rock datasets from the two play types of the southern margin of the Mid North Sea High A) well 42/10a-1, Yoredale Formation of the 'Visean-Namurian clastic play', B) well 43/17-2 of the Millstone Grit, Upper Bowland Shale, Cleveland D and E units of the 'ViseanNamurian basinal play'. TOC= Total Organic Carbon 
Analysis of new and legacy data from wells on the northern parts of Quadrants 41-43 identified a number of wells with gas-prone intervals, good to excellent source rock potential in the Yoredale and Scremerston formations (e.g. 42/10b- 2, 41/15- 1, 42/09- 1, 42/10a- 1 e.g. Figure 8a) and maturity levels ranging from oil to gas mature. Commonly these data indicate good quality source rocks which are immature to oil mature (e.g. Figure $8 \mathrm{a}$ ), and would offer hydrocarbon potential if similar strata were more deeply buried in adjacent basins.

Wells in central and southern parts of Quadrants 41-43 (e.g. 41/14-1, 41/20-1, 43/17- 2) have thick (up to c. $2 \mathrm{~km}$ proved) fair to excellent TOC-rich successions within the Cleveland Group that exhibit generally low S2 (an indicator of remaining hydrocarbon generative potential) values (e.g. Figure 8b). The mudstone-dominated unit of the Upper Bowland Shale which has characteristically high gamma ray wireline signature is within this Group (Kearsey et al., 2015, in press; see Figure 9). Samples vary from oil to gas mature, to overmature, suggesting that some depletion of the source rock could have occurred due to hydrocarbon generation. This is supported by peaks in the S1 index (a measure of free oil and gas content) and production index (PI; Figure 8b), and by basin modelling (section 7). These data indicate gas-mature source rocks that may have generated some hydrocarbon and may now be depleted or overmature at deeper levels. A contributory factor to low S2 values may also be the large proportion of woody and inert kerogens referred to in some well reports (e.g. Sauer, 1992 in 


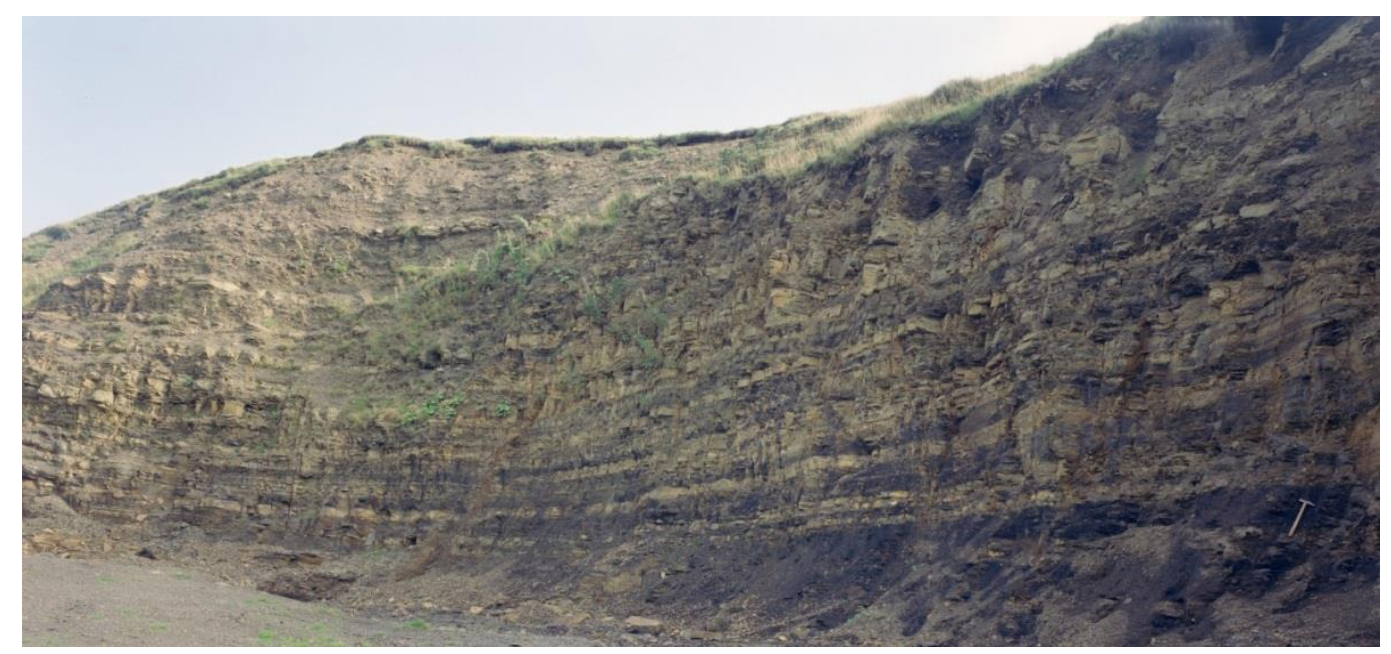

Figure 9 Example of the Upper Bowland Shale at outcrop, in a quarry at Bleasdale, Lancashire [British National Grid 358880, 445040]. An onshore analogue for basinal mudstones offshore in southern parts of Quadrants $41-43 . ~ \sim 30 \mathrm{~cm}$ long hammer, bottom left for scale. BGS Photo P213491 BGSCNERC. All Rights Reserved 2016.

Petrophysical analysis showed that basinal Cleveland Group strata have average TOC contents between $1.5-3.4$ weight (wt) \%. Between $64-98 \%$ of the stratigraphic unit comprises mudstone with TOC levels greater than 1 wt \% (Table 1). In some wells (e.g. 43/17-2) the calculated total thickness of Cleveland Group mudstone with a TOC $>1 \mathrm{wt} \%$ is more than $1400 \mathrm{~m}$ (Gent, 2015). Whereas particular units, such as marine bands or the Upper Bowland Shale are particularly organic rich, it is notable that there is a very thick succession of rocks which have a fair to good source rock quality. Measurements from 6 wells in the Yoredale Formation clastic play on the southern margin of the MNSH indicate average TOC contents of mudstone between $1.8-3.4$ wt $\%$ with $50-74 \%$ of the unit containing mudstone with TOC levels greater than $1 \mathrm{wt} \%$. Similar values were obtained for 5 wells in the Scremerston Formation on the southern side of the MNSH with a $34-65 \%$ mudstone succession with average TOC $1.3-4.1 \mathrm{wt} \%$. For 12 wells penetrating the Millstone Grit Formation, 1 $-71 \%$ of the unit was mudstone with average TOC $1.4-2.7 \mathrm{wt} \%$ (Table 1). The mudstone intervals within these units are commonly tens of metres thick and calculated thickness of mudstone with TOC values > $1 \mathrm{wt} \%$ is commonly between $100-500 \mathrm{~m}$ (Gent, 2015). 


\subsection{NORTH DOGGER AND QUADRANT 29 BASINS}

The Scremerston Formation was mapped into the Quadrant 29 basin based on characteristic reflectivity (Arsenikos et al., 2015, in press; Hay et al., 2005). A Palaeozoic source for the gas chimneys identified in Quadrant 29 by Hay et al. (2005) was not clear during seismic interpretation of more recent data by Arsenikos et al. (2015; in press). There are no well penetrations beneath the Permian to prove Carboniferous strata in the Quadrant 29 basin. Several wells in Quadrant 29 have oil shows in the Rotliegend Auk sandstone (29/20-1, 29/18-1 (weak gas shows), 29/23-1, 29/25-1) or Zechstein (29/20-1, PA Resources, 2011). Geochemical typing of samples from wells in this area interprets oil from 29/20-1 to be from an early mature Carboniferous lacustrine (not Devonian) source using biomarker analysis (Copestake et al., 2009). Isotopic signatures on shows and inclusions in 29/10-3st1 were attributed to a Carboniferous coal-bearing source in Farris et al. (2012).

Carboniferous well penetrations at the margins of the North Dogger Basin encountered weak gas shows in 38/16-1 and poor oil shows in 39/07-1 (Amoco Petroleum, 1967; Hay et al., 2005). In the adjacent Netherlands sector along the same structural configuration, gas and oil shows are present in wells e.g. A15-01, A14-01 north of the Elbow Spit high, distant from a Jurassic source (Figure 1; EBN, 2015a, b; ter Borgh et al., in press a). Schroot et al. (2006) and ter Borgh et al. (in press a) document pre-Westphalian prospectivity in this region. Arfai and Lutz (2017) report a ViseanNamurian source rock for the A6-A gas field in the adjacent German sector and illustrate spatially variable modelled maturity levels.

Source rock quality for the Scremerston Formation was judged to be excellent in $38 / 18-1$, poor to excellent in 38/16-1, and gas-prone with some oil-prone intervals (Vane et al., 2015; e.g. Figure 10a). In 39/07-1 significant thicknesses of coal occur in the Scremerston Formation. Oil window maturity levels were measured at Scremerston and/or Yoredale Formation source rock level in the basin margin wells sampled (e.g. VR= 0.39-0.66 38/16- 1; see also Vane et al., 2015; Figure 10a). 
Petrophysical calculations on the few Visean-Namurian well penetrations, indicate a less mudstoneand less organic-rich succession than those in Quadrants 41-43. For example, three wells in the Scremerston Formation (38/16-1, 38/18-1, 39/07-1) gave average calculated TOC of $1.4-2.5 \mathrm{wt} \%$ with only $20-39 \%$ of the succession being mudstone $>1$ wt\% TOC (Gent, 2015). There are however, significant coals, e.g. over a total of $20 \mathrm{~m}$ of coal in 39/07-1. These findings are in agreement with the lithological well analyses of ter Borgh et al. (in press a) who describe a similar 'overfilled clastic play' along strike in The Netherlands sector, passing basinward to a 'starved shale play' south and east of the Elbow Spit High. 

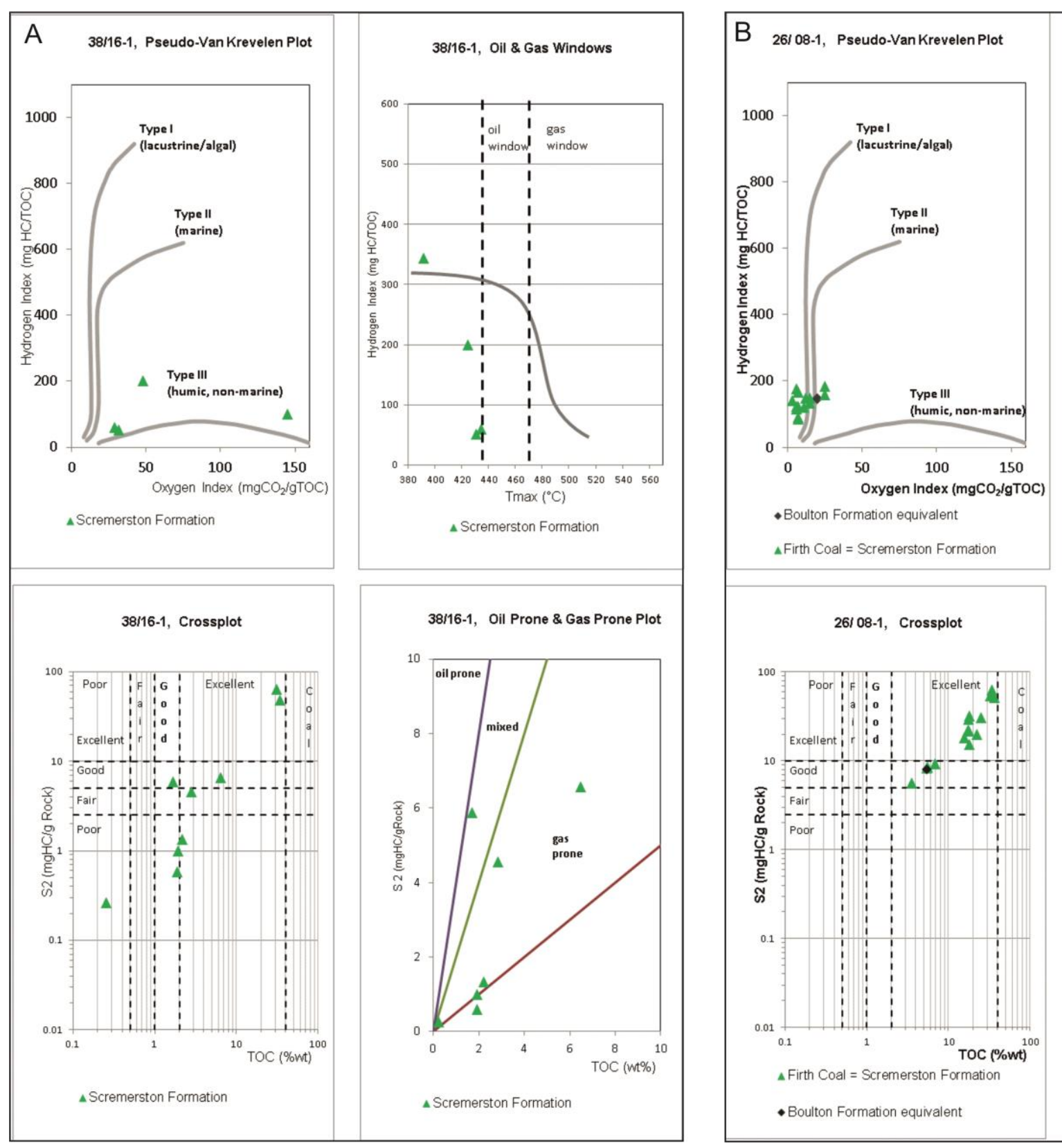

26I 08-1, Oil \& Gas Windows

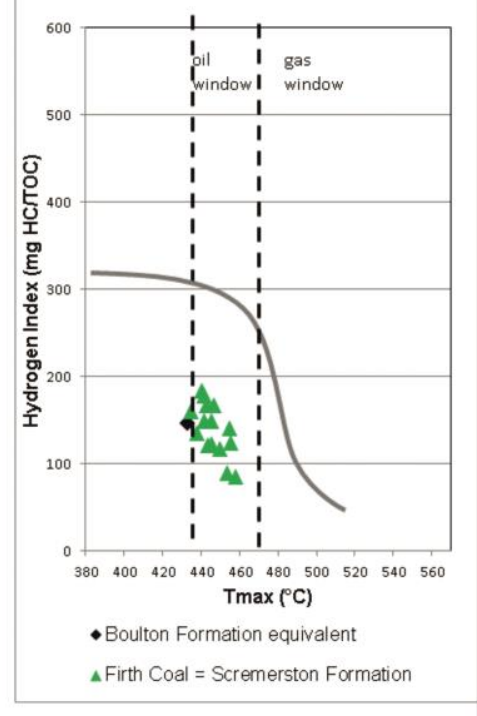

26/ 08-1, Crossplot

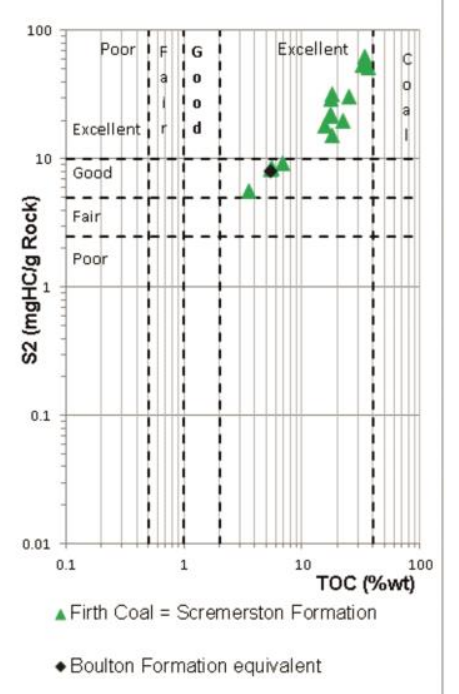

26/ 08-1, Oil Prone \& Gas Prone Plot

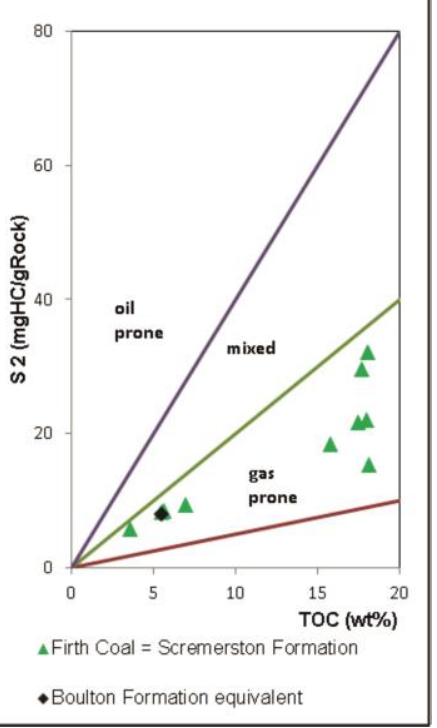


Figure 10 Typical source rock datasets from A) well 38/16- 1, Scremerston Formation of the 'Visean-Namurian clastic play', margin of the North Dogger Basin B) well 26/08-1, of the Firth Coal=Scremerston units of the 'Visean-Namurian clastic play', Forth Approaches Basin. 


\subsection{MID NORTH SEA HIGH}

Samples from two wells (36/13-1 and 36/23-1) show that the source rock potential of the Yoredale Formation in this area is judged to be good to excellent (e.g. S2 commonly in tens and up to 160 $\mathrm{mg} / \mathrm{g}$ ), and mainly gas-prone with some oil-prone intervals (Vane et al., 2015). However, maturity levels only reached pre-oil to oil levels in the analysed samples.

Petrophysical calculation of TOC content in the Yoredale Formation from 36/13-1 gave mudstones of average 2 wt\% TOC, with $37 \%$ of the unit containing mudstone with TOC > 1wt\% (Gent, 2015). As coals are present but were excluded from the petrophysical analysis, these summary values are pessimistic indicators of source rock presence. No other Carboniferous source rock units were penetrated or analysed in wells across the MNSH (Quadrants southern 26-37).

\subsection{FORTH APPROACHES BASIN}

The Scremerston/Firth Coal Formation forms the source rock in the Forth Approaches Basin, with gas and oil shows in well 26/08- 1 (Mobil North Sea Ltd, 1992, 1993). Coals form a significant component of the succession, which is age-equivalent of the Scremerston Formation to the south and east of the MNSH, and the organic-rich, oil-prone lacustrine West Lothian Oil-Shale Formation of the onshore Midland Valley of Scotland (Cameron 1993 a, b; Kearsey et al., 2015; Loftus and Greensmith, 1988, Parnell, 1988). Westphalian strata, age-equivalent to the Coal Measures, are recorded in well 26/08- 1 and though mudstone intervals are present, coals are lacking.

Source rock quality of the largely gas-prone Firth Coal/Scremerston Formation varies from poor to excellent in 26/07- 1 and 26/08- 1 with oil window maturity levels indicated in the sampled wells (Figure 10b; Vane et al., 2015). 
Petrophysical calculation on the Firth Coal/Scremerston Formation interval datasets from 26/07- 1 and 26/08- 1 gave an average TOC content of mudstones of $1.6-3.0$ wt\% with $44-45 \%$ of the unit containing mudstone with TOC> 1wt\% (coals excluded; Gent, 2015).

\section{Visean-Namurian reservoir rocks}

Major, stacked channel sandbodies and palaeovalley fills within the Fell Sandstone, Scremerston, Yoredale and Millstone Grit formations have been documented previously as potential reservoir intervals (Collinson and Jones, 1997; Collinson, 2005; Jones, 2007; Maynard and Dunay, 1999). Using onshore exposures of age-equivalent strata (e.g. Figure 11) and offshore borehole data, Jones (2007) interpreted the largest stacked major channel systems to be up to about $27 \mathrm{~m}$ thick and up to $8 \mathrm{~km}$ wide, with net to gross commonly $>0.8$. 


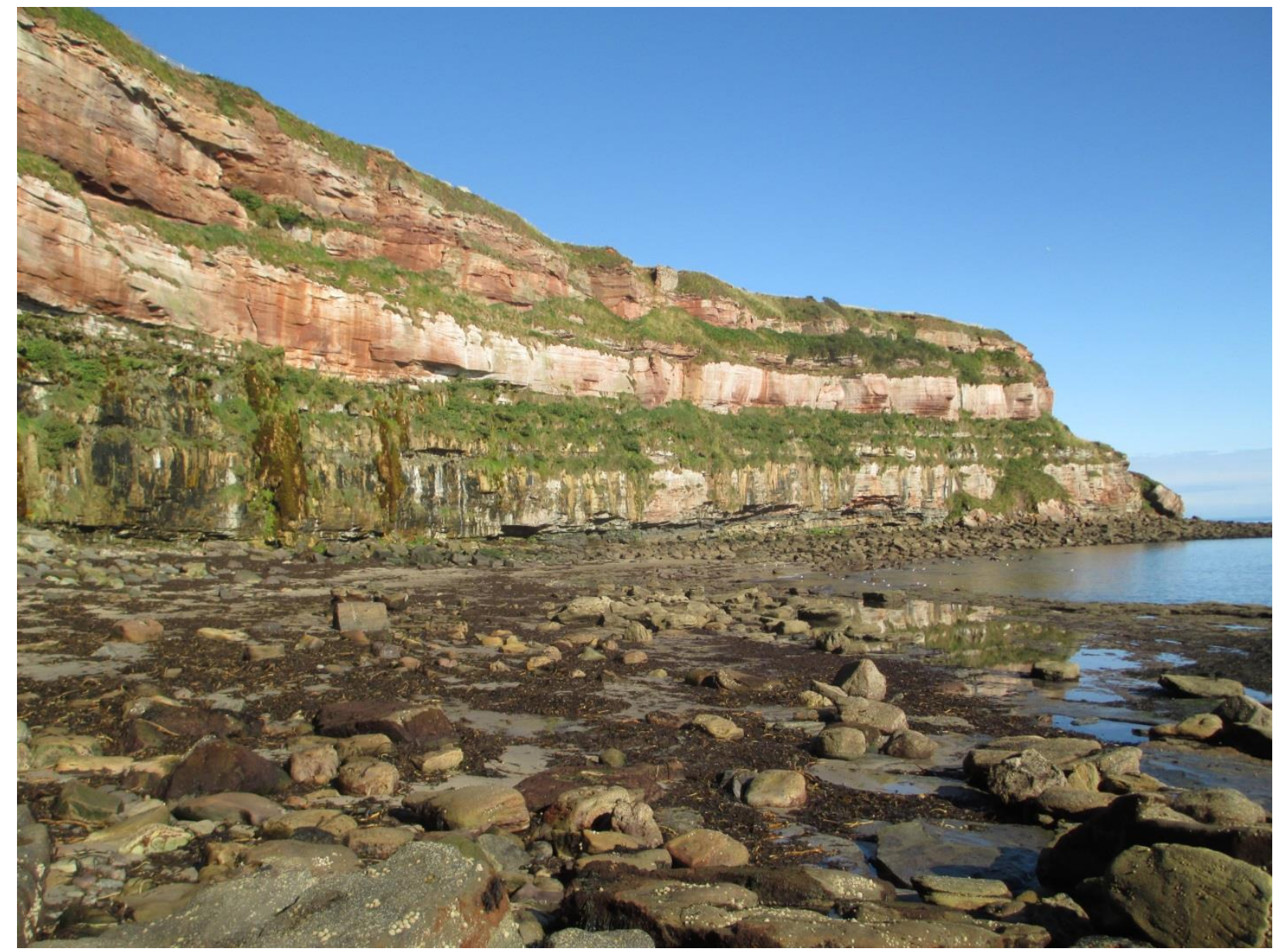

Figure 11 Visean multistorey channel sandstone forming the cliff at Marshall Meadows Bay, Berwick-upon-Tweed [British National Grid 398169,657040], an analogue for offshore reservoir sandbodies. The top of the Scremerston Formation is marked by the limestone which occurs within the grassy interval in the cliff above the lowest thick sandstone.

The reservoir interval in the Breagh Field comprises Visean channel sandstones within the Yoredale Formation (RWE Dea, 2011a; Symonds et al., 2015). Symonds et al. (2015) also highlighted the reservoir role of Yoredale Formation sheet sandstones intervals across a $17 \mathrm{~km}$ well correlation panel in and around the Breagh Field, with permeabilities of $0.1-100 \mathrm{mD}$ given.

On the southern margin of the MNSH, transgressive quartzitic sandstones and low-kaolinite sandstones form a relatively high permeability reservoir target in Namurian and early Westphalian successions (Blackbourn and Collinson, 2006; Collinson and Jones, 1997). Millstone Grit Formation sandstone is the reservoir in the Trent and Cavendish fields in southern parts of Quadrant 43 
(Cameron et al., 2005; Kombrink et al., 2010; O'Mara et al., 2003). Onshore studies of Millstone Grit Formation sand bodies to turbidite-fronted deltas (Church and Gawthorpe 1994, Hampson 1997, Jones and Chisholm 1997) offer insight to offshore Visean-Namurian sand body geometry and correlation, though lack of correlative chronostratigraphic data and large well spacing precluded detailed study offshore.

Regional screening of potential reservoir-rock intervals was undertaken using petrophysical techniques calibrated with measured core data, to identify intervals with the greatest net to gross and porosity values throughout the succession (Figure 3; Hannis, 2015). Though only 12 wells had suitable log curves and only 7 had measured core data, it was possible to quantify the most favourable reservoir quality occurring within sandstones in the Yoredale, Scremerston and Fell Sandstone formations (Table 2). Core measured porosity is variable, reaching up to $26 \%$ in the Scremerston Formation in 26/07-1, though permeabilities are generally less than $20 \mathrm{mD}$, with rare exceptions up to $1460 \mathrm{mD}$. . 


\begin{tabular}{|c|c|c|c|c|c|c|}
\hline \multirow[b]{2}{*}{ Formation } & \multicolumn{3}{|c|}{$\begin{array}{c}\text { Log curve derived } \\
\text { (calibrated using core } \\
\text { measured) }\end{array}$} & \multicolumn{2}{|c|}{ Core measured } & \multirow[b]{2}{*}{$\begin{array}{c}\text { Data available (number of wells used } \\
\text { in log curve derived values, core data } \\
\text { available) }\end{array}$} \\
\hline & NTG & $\begin{array}{c}\text { Highest } \\
\text { Average } \\
\text { PHIE } \\
(\%)\end{array}$ & \begin{tabular}{|c|} 
Highest \\
Average \\
Estimated \\
Permeability \\
(mD)
\end{tabular} & \begin{tabular}{|c|} 
Highest \\
Average \\
Core \\
Porosity \\
$(\%)$
\end{tabular} & $\begin{array}{c}\text { Highest } \\
\text { Average Core } \\
\text { Permeability } \\
\text { (Kair, mD) }\end{array}$ & \\
\hline Grensen Formation & 0.58 & 12 & - & 4 & & 1 well, No core data, \\
\hline Millstone Grit Formation & 0.24 & 9 & 0.2 & 9 & 0.1 & 1 well. Core data $43 / 21-2$ \\
\hline Yoredale Formation & 0.27 & 19 & 144.5 & 13 & 39.2 & 4 wells. Core data 41/01-1, 42/10a-1 \\
\hline Cleveland Group 'E' & 0.01 & 7 & 0.1 & 2 & 0 & 1 well. Core data $43 / 21-2$ \\
\hline Upper Bowland Shale & 0.08 & 7 & 0.1 & 2 & 0 & 1 well. Core data $43 / 21-2$ \\
\hline Cleveland Group 'D' & 0.07 & 7 & 0.1 & 1 & 0 & 1 well. Core data $43 / 21-2$ \\
\hline Scremerston Formation & 0.18 & 15 & 261.4 & 18 & 295.0 & 6 wells. Core data 26/07-1, 42/15a-2 \\
\hline Fell Sandstone Formation & 0.61 & 13 & 15.6 & 4 & 0.2 & 4 wells. Core data $41 / 01-1$ \\
\hline Cementstone Formation & 0.11 & 10 & 0.1 & 81 & & 2 wells. No core data \\
\hline Tayport Formation & 0.49 & 13 & - & - & & 2 wells. No core data \\
\hline Buchan Formation & 0.48 & 12 & - & 6 & 0 & 3 wells. Core data $37 / 12-1$ \\
\hline
\end{tabular}

Table 2. Summary of NTG, average porosity and average permeability from log curve derived net intervals and core measured data for Carboniferous to upper Devonian units from selected wells in and around the MNSH, from Hannis (2015). Note the limited number of wells having both suitable log curve datasets and measured core data. PHIE=effective porosity, NTG=Net to Gross.

The maximum measured porosity generally decreases with increasing present day depth. A simple depth versus porosity function is not evident in the porosity datasets because of the restricted spatial extents of the data from different formations, combined with multiple phases of burial and uplift that varies between wells.

\subsection{FELL SANDSTONE FORMATION}

The Fell Sandstone Formation is a clear candidate for a reservoir interval as it predominantly comprises coarse-grained sandstone deposited in a major braided fluvial system. Onshore, the Fell Sandstone Formation is an important aquifer supplying water for Berwick-upon-Tweed (Turner et al., 1993). It is the reservoir interval in the Errington- 1 well, onshore, and was reported to have limited gas shows and a maximum porosity of $6 \%$ (ROC Oil, 2005). Maynard and Dunay (1999) recognised 
the reservoir potential offshore stating Net to Gross (NTG) exceeding 0.70 and Hay et al. (2005) summarised porosity data indicating a range of $5-19 \%$.

In the wells examined for the petrophysical study in the southern MNSH margin, the Fell Sandstone Formation has a NTG ranging from $0.34-0.82$ with calculated average porosity ranging from $6-13$ $\%$. However, the largest average estimated permeability is $16 \mathrm{mD}$ (Hannis, 2015). Core material from the Fell Sandstone Formation in $43 / 02-1$, has an average porosity of $13 \%$ and average horizontal permeability of $18 \mathrm{mD}$ (Redwood Corex, 1989).

\subsection{YOREDALE AND SCREMERSTON FORMATIONS}

On the southern MNSH margin, petrophysical screening of 3 wells (41/01-1, 42/10a-1, 43/21-2), showed that relatively large average calculated porosities of up to $12 \%$ were found in parts of the Yoredale Formation. Despite a NTG of up to 0.31 , the net has relatively high estimated permeabilities, averaging $144.5 \mathrm{mD}$ in $41 / 01-1$. In the Scremerston Formation the largest average calculated porosity is $12 \%$ (based on 3 wells, 41/01-1, 42/15A-2, 44/02-1), but it has a relatively low NTG of 0.24 (Hannis, 2015).

Petrophysical screening of well 39/07-1 at the margin of the North Dogger Basin has shown the Yoredale Formation to have average calculated porosity of $13 \%$ and NTG of 0.26 . Values for the Scremerston Formation include an average calculated porosity of $15 \%$ and NTG of 0.49 in 38/18-1.

The relatively low NTG in the Scremerston and Yoredale formations and variable but locally high porosity-permeability is compatible with the interbedded and laterally variable lithologies that include incised valley fill, channel and sheet sandstone facies.

In the Forth Approaches, the main reservoir target in this area is likely to be the Rotliegend Auk Formation sandstones that are $150 \mathrm{~m}$ thick in 26/07- 1 with core-measured porosities of $6-24 \%$ and permeability up to hundreds of millidarcies. Additional potential reservoirs are present throughout the heterolithic Carboniferous succession. Relatively high porosity and permeability 
values of the Firth Coal/Scremerston Formation core samples (Table 2) in 26/07- 1 were from cores taken from $5-15 \mathrm{~m}$ thick sand bodies.

\section{Traps and Seals}

The primary regional top seal on and around the MNSH area is Zechstein Group evaporites. For example, the Breagh Field comprises a faulted structural closure of Yoredale Formation sand bodies beneath a Zechstein seal (Symonds, 2015; Symonds et al., 2015). The effectiveness of the seal is reduced where halokinesis has created thinned zones, or the succession deposited is thin with a higher proportion of carbonate versus evaporite (e.g. northern parts of Quadrants 38, 39). These thinned successions generally contain a higher proportion of competent strata and are thus more susceptible to faulting and fractures. Carbonates form proved reservoirs within the Zechstein succession (e.g. Auk, Argyll Fields; Glennie et al., 2003). In addition, intraformational Carboniferous seals could have been very important in preventing migration of hydrocarbons out of the system, as well as creating possibilities for additional intra-Carboniferous prospectivity at depth(s) beneath a regional Permian seal.

In southern parts of Quadrants 43 and 44, the Permian Silverpit mudstone seal is also present, e.g. Schooner and Ketch fields (Cameron et al., 2005; Underhill, 2003).

Detailed local study is required to map the likely extent, thickness and integrity of potential intraformational Carboniferous mudstone seals and, although these may be viewed as risky (see Besly, in press), they are proved in a number of fields. For example, the Boulton Field reservoirs are separated by an intra-Carboniferous seal (Conway and Valvatne, 2003) and the Trent Field produces from a Namurian reservoir shown at some distance below a higher Westphalian A reservoir (O'Mara et al., 2003), implying an intra-Carboniferous seal is in place. Onshore UK, there are examples in the 
West Firsby and Welton fields of intraformational Carboniferous seals where pro-delta mudstones overlie marine bands in deltaic cyclothems (Kombrink et al., 2010; Pharaoh et al., 2011). The Saltfleetby Field onshore is an example of successful entrapment of gas beneath Westphalian A mudstone-dominated strata (Cameron et al., 2005; Hodge, 2003).

A variety of structural (faulted and folded) and dip/unconformity traps can be interpreted from seismic sections in and around the MNSH study area, primarily at the base Permian unconformity (Figure 12). Stratigraphic traps are possible for isolated channel sand bodies, particularly within the mudstone-dominated basinal play (Figure 12). A variety of these trapping styles are documented in relinquishment reports (e.g. PA Resources, 2011; RWE Dea, 2011b). 


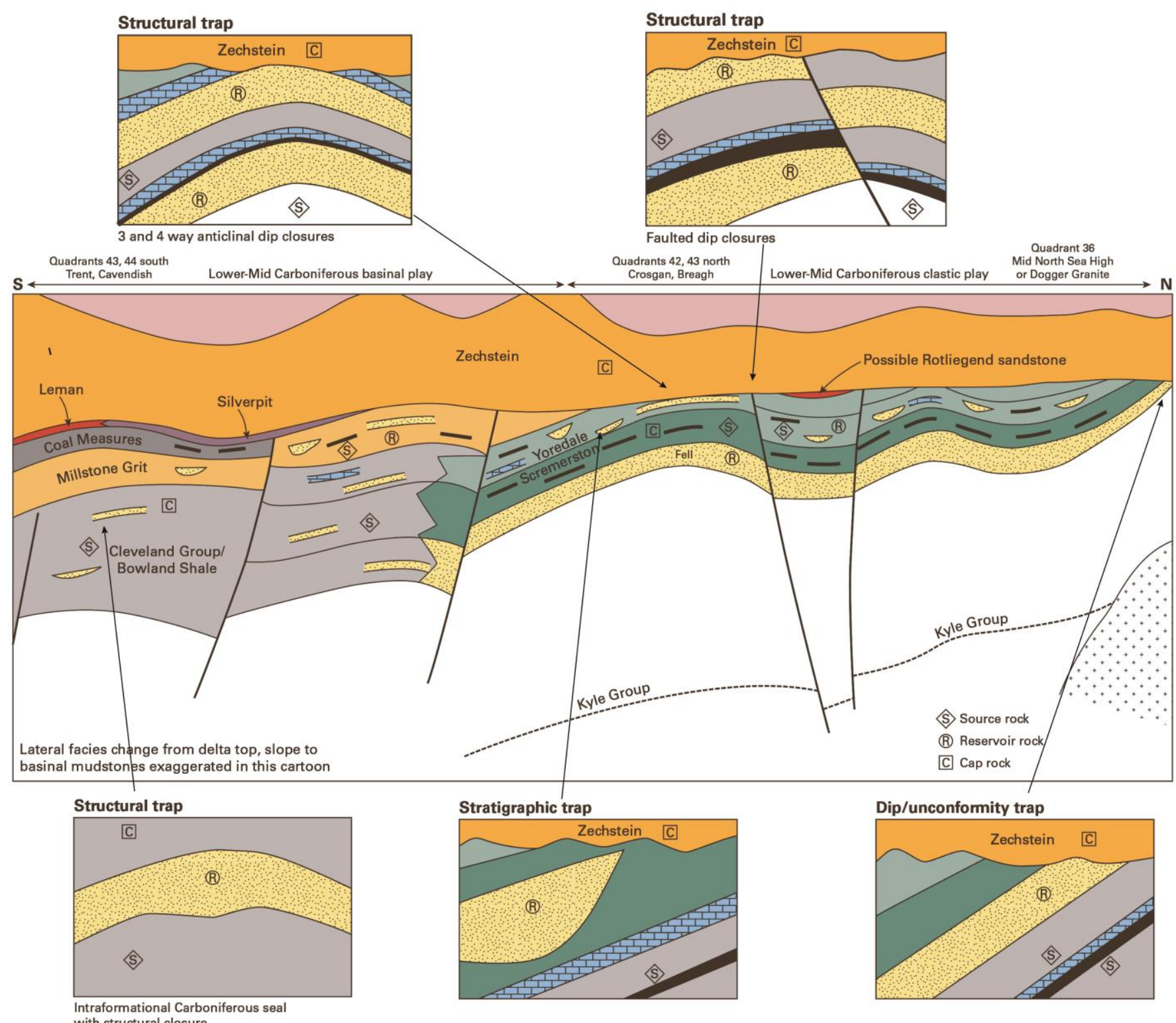

Figure 12 Summary of trap styles observed or envisaged on the southern margin of the Mid North Sea High 


\section{Basin Modelling}

Previous thermal basin modelling studies of Carboniferous source rocks have highlighted variability in predicted oil/gas generation and its timing, largely due to spatial variability in depositional lithofacies and the timing and amount of uplift/burial, as well as in uncertainty in data input (e.g. Collinson et al., 1995, Quadrants 41 - 43; Hay et al., 2005 Quadrant 29; Granby and TGS Nopec, 2010, Quadrant 26). To further understand the likely location and timing of oil and gas generation in and around the MNSH, a set of nine wells having the best available source rock geochemistry and maturity datasets were selected for 1D basin modelling studies by Vincent (2015), upon which this section is based. Though well data is generally only available for structural highs, a representative set of structural locations was attempted to be chosen (Figure 4). Full use was made of seismic interpretations and density/velocity variations to constrain burial and uplift history, though this remains a major uncertainty, along with palaeo-heat flow values.

\subsection{D BASIN MODELLING SOUTH OF THE MID NORTH SEA HIGH}

Basin modelling was undertaken in three wells; 41/14-1, 41/20-1 situated offshore in the Cleveland Basin, and 43/17-2 situated along strike in the Silverpit Basin (Figure 13). These wells penetrate the Visean-Namurian 'basinal play' and contain Carboniferous strata of the Coal Measures to Cleveland groups. Based on Rock-Eval data and geochemical well reports, organic matter with a mix of oil- and gas-prone kerogens and a generation potential from moderate to good was included. Numerous gas shows have been reported from the modelled wells (e.g. Anadrill, 1990; The Geochem Group, 1991).

A fourth modelled well, 42/10b-2, is located farther north within Visean-Namurian strata of the 'clastic play' . It is situated on a local high and is the well that proved the Agincourt/Crosgan gas discovery within the Yoredale and Scremerston formation reservoirs (Hay et al., 2005; Kaye, 1996; Premier Oil, 2008; Figure 4). 
For wells 41/14-1, 41/20-1 and 43/17-2, basin modelling indicates maximum burial during Cenozoic times of Visean-Namurian strata that have reached the late maturity window for oil and gas, and in some intervals are likely to be overmature (e.g. Cleveland Group A and B in 41/14-1; Cleveland Group $D$ in 43/17-2). All three wells modelled indicate hydrocarbon generation in the late Carboniferous and Mesozoic-Cenozoic times from the Cleveland Group, Millstone Grit Formation and Coal Measures Group (Figure 13). The possibility of some Carboniferous depletion of gas-prone source rocks is clear in 41/14-1 and 43/17-2 (Figure 13), before Variscan-related structural traps and the Silverpit mudstone and Zechstein evaporite seals were in place. Intraformational Carboniferous mudstone seals could have been effective but may have been breached by subsequent tectonic events.

In well 42/10b-2, lower maturity levels resulted in a burial history model of gas generation from the Scremerston interval during Cenozoic times, when Zechstein and younger strata would have provided a seal (Figure 13). 

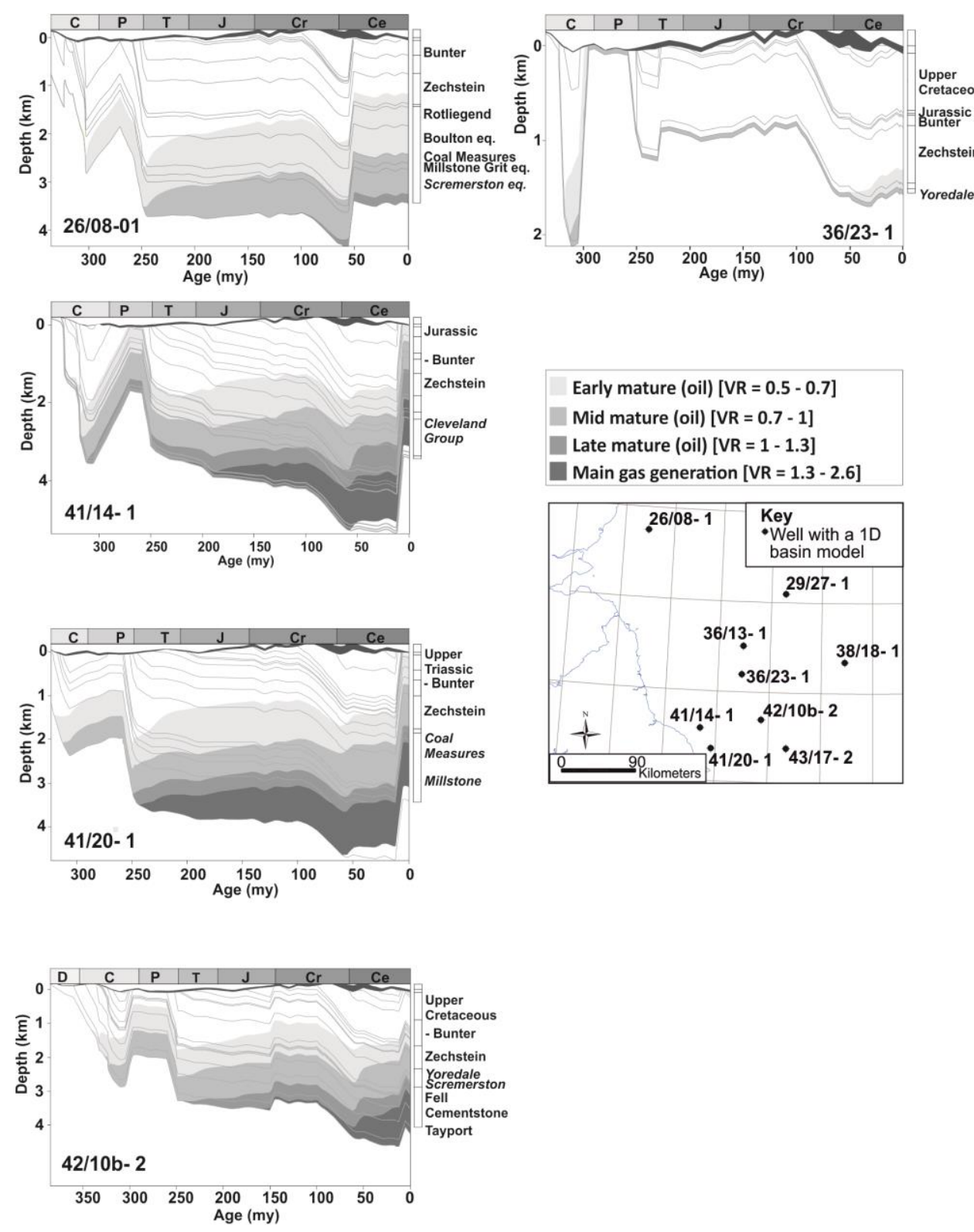
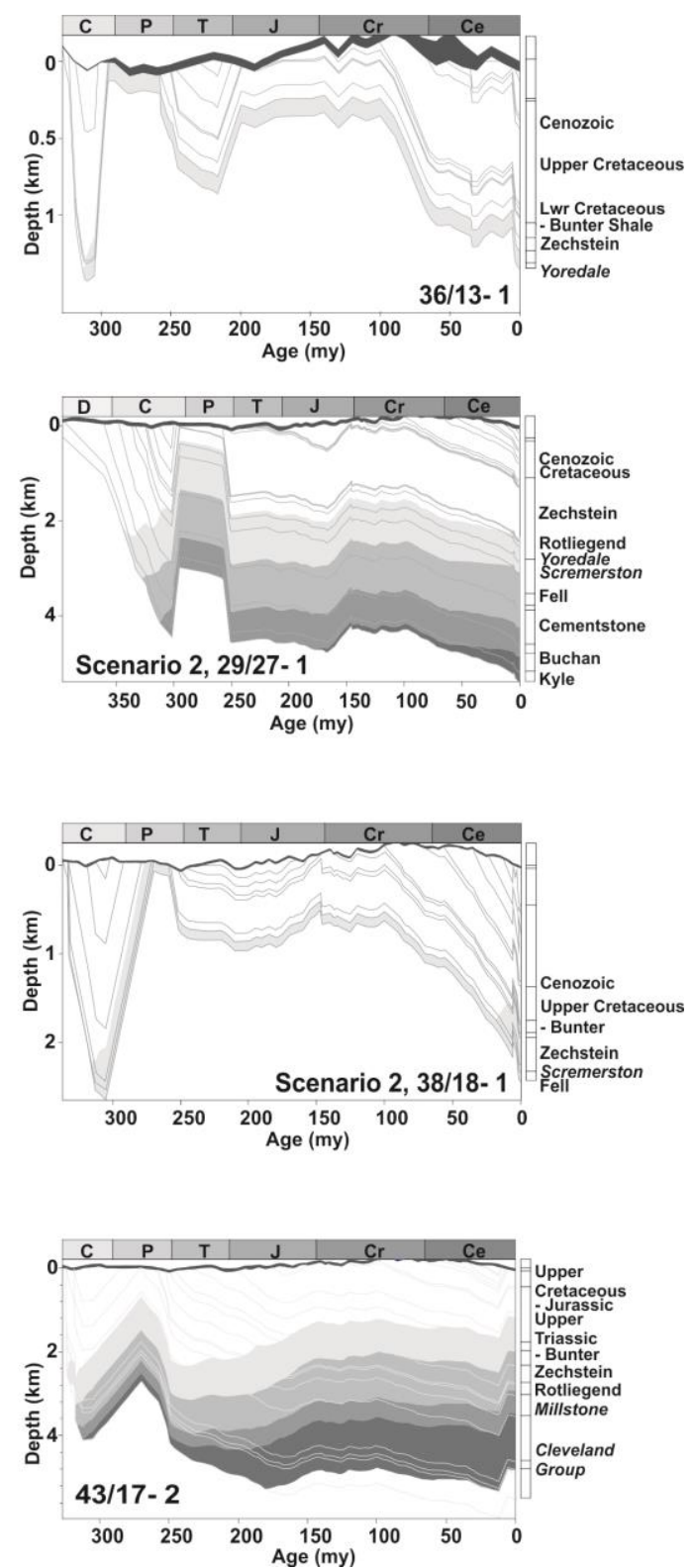
Figure 13 Summary of thermal and burial history curves for 1D basin models, summarised after Vincent (2015). Carboniferous source rock intervals are in italics. $\mathrm{D}=$ Devonian, $\mathrm{C}=$ Carboniferous, $\mathrm{P}=$ Permian, $\mathrm{T}=$ Triassic, $\mathrm{J}=\mathrm{Jurassic}, \mathrm{Cr}=\mathrm{Cretaceous}, \mathrm{Ce}=\mathrm{Cenozoic}$, VR=vitrinite reflectance, summary stratigraphic or chronostratigraphic names shown. The burial histories labelled with 'scenario 2' are very poorly constrained by maturity and well data and so a range of scenarios were modelled. 


\subsection{D BASIN MODELLING IN THE NORTH DOGGER - QUADRANT 29 BASINS}

As no wells penetrate the Carboniferous of the Quadrant 29 basin or the centre of the North Dogger basin, maturity modelling was undertaken for various 'scenarios' for wells 38/18-1 and 29/27-1 (Figure 13) to better constrain whether hydrocarbon generation may have occurred in these regions. Data from surrounding wells were used, along with seismically interpreted depths to Carboniferous horizons.

Well 29/27-1 lies on the southwestern margin of the Quadrant 29 basin and terminated in the Rotliegend Group. Interpretation of fluid inclusion studies and geochemical typing of oil shows in wells $29 / 20-1$ and 29/10-3st1 to the northeast of the Quadrant 29 basin suggest a Carboniferous lacustrine and coal source rock (Copestake et al., 2009; Farris et al., 2012). For 29/27-1, a hypothetical well was modelled to be at early oil window maturity at Scremerston Formation source rock level, with deepest burial occurring during Cenozoic times (Scenario 2, Figure 13). Source rocks were modelled with dominantly gas-prone kerogens. An additional $3.5 \mathrm{~km}$ of Carboniferous burial would be required to place the Scremerston Formation in the gas window (Scenario 3 of Vincent, 2015). Seismic mapping shows the top Scremerston to be approximately $1.25 \mathrm{~km}$ deeper in the centre of the Quadrant 29 basin than at the position of 29/27-1 (Arsenikos et al., 2015, in press). The simplistic hypothetical burial modelling does not therefore predict that the Scremerston Formation is likely to reach the gas window in the Quadrant 29 basin. However, the basin modelling is constrained by few data and the confidence in this hypothetical well model is low .

The results of the Quadrant 29 recent modelling initially appear to contrast with those of Hay (2005) who predicted gas generation and migration from the deepest parts of the Quadrant 29 basin. On closer examination, hypothetical wells that were predicted to enter the gas window invoked the burial of Carboniferous rocks to around 5 or $6 \mathrm{~km}$ (Hay et al., 2005). These depths are inconsistent with the seismic interpretation and the depth conversion of the Scremerston Formation source rock intervals mapped in Arsenikos et al. (2015, in press). In contrast, and highlighting the uncertainties 
caused by the lack of well and sample data, a relinquishment report from southern Quadrant 29 (ConocoPhillips, 2011) predicted the lower Carboniferous coals and shales to be mature for gas generation with charge occurring when the seal and trap were in place.

Well 38/18-1 is situated on a local high on the western flank of the North Dogger Basin (Figure 4) and terminates in the Fell Sandstone Formation. Oil staining was observed in the Scremerston Formation in 38/18-1 (Paleochem Ltd, 1984) and minor gas shows have been reported in 38/16-1 (Amoco, 1967). The 1D basin model of well 38/18-1 was constrained by limited amounts of measured data in the oil- and gas-prone Scremerston and Fell Sandstone formations, which were modelled as reaching early oil window maturity (Scenario 2 on Figure 13; Vincent, 2015). An additional $3.5 \mathrm{~km}$ of Carboniferous burial was modelled to be required to facilitate gas window maturity (Scenario 3 of Vincent, 2015). In the deepest parts of the North Dogger Basin the base of the Scremerston Formation is mapped as approximately $1.6 \mathrm{~km}$ deeper than in 38/18-1 (Arsenikos et al., 2015, in press). Based on the current data assumptions and the low confidence 1D basin model, gas maturity of the Scremerston Formation in the basin centre is predicted not to occur. The Scremerston Formation is expected to be a viable mature source rock for oil in the North Dogger Basin assuming it has similar facies in the basin centre, to those proved by well $38 / 18-1$ on its flanks.

In summary, maturity levels at basin margins, likely burial depths in basin centres, and oil shows in wells at basin margins provide evidence that the North Dogger and Quadrant 29 basins have been, or are, oil generative. However, the volume and timing of generation is uncertain. In the basin centres, some basin modelling studies have predicted gas generative potential, whilst others have not, highlighting the lack of data and low confidence of 'scenario' or 'hypothetical' models.

\subsection{D BASIN MODELLING OVER THE MID NORTH SEA HIGH}

Basin modelling was undertaken on wells $36 / 13-1$ and 36/23-1 which penetrated the ViseanNamurian Yoredale Formation, although constrained by a limited amount of geochemistry and 
maturity data (Figure 13). The wells are representative of the MNSH, with seismic evidence of a thinning of the Carboniferous succession and a relatively thin overburden encompassing periods of non-deposition and erosion. Well 36/13-1 is located east of the Farne Granite on a local high and 36/23-1 on a local, faulted high within a Carboniferous depocentre (Figure 4). Both wells reported some UV fluorescence indicating the presence of hydrocarbons (Applied Petroleum Technology, 2012) and 36/13-1 recorded weak gas shows in Zechstein and Jurassic strata (Arpet, 1967).

1D basin modelling of well 36/13-1 indicates that early oil maturity of the Yoredale Formation strata was reached in late Carboniferous times, followed by Variscan and Mesozoic uplift and further Cenozoic burial (Figure 13). A similar maturity development profile, but reaching mid oil maturity levels, is interpreted for 36/23-1, $35 \mathrm{~km}$ to the south (Figure 13). Given that the source rock intervals are judged to be largely gas-prone with some oil-prone intervals, little or no petroleum generation is modelled, and deepest burial (and generation) is prior to the deposition of the regional Zechstein seal for both these wells. The Yoredale Formation strata modelled at the well locations are not expected to contain mature, hydrocarbon generative source rocks . Yoredale and underlying Scremerston formation strata buried more deeply in the south of Quadrant 36, or in adjacent basins, have the potential for higher maturity levels and thus hydrocarbon generation.

\subsection{D BASIN MODELLING IN THE FORTH APPROACHES BASIN}

Previous basin modelling and fluid inclusion work in the Forth Approaches Basin have suggested both a late Carboniferous phase of hydrocarbon migration with charge before traps and seals were in place (Glenister et al., 2001) and a Mesozoic-Cenozoic gas generative phase, once traps and seals were in place (Granby and TGS Nopec, 2010).

Well 26/08-1 is situated towards the southeastern margin of the Carboniferous Forth Approaches depocentre and penetrates strata of Triassic, Permian and Carboniferous age (Boulton, Coal Measures, Passage and Firth Coal/Scremerston formations; Kearsey et al., 2015 interpretation). Oil 
shows are noted in sandstones of the Firth Coal/Scremerston Formation, with gas shows in the Carboniferous, Rotliegend and Zechstein groups (Mobil North Sea, 1992, 1993). Oil and gas shows in Carboniferous and Rotliegend intervals have been assumed (Glenister et al., 2002) and proved by geochemical typing (Farris et al., 2012) to be sourced from Carboniferous strata.

Basin modelling of well 26/08-1 indicates that early oil maturity was attained during Carboniferous burial, and mid-late oil maturity during Mesozoic-Cenozoic deeper burial of the Firth Coal/Scremerston Formation source rock interval (Figure 13). However, as the sampled succession is largely gas-prone, significant quantities of oil or gas are not predicted to have been generated at the location of this well . Relatively small amounts of additional burial (compared with the studied well or a more oil-prone succession, both of which could occur in the Forth Approaches Basin), could significantly enhance the prospectivity of the lower Carboniferous petroleum system. Carboniferoustyped oil and gas shows and fluid inclusion studies in this well and 26/04-1, 26/07-1, and 26/12-1 (Glenister et al., 2001; Farris et al., 2012; Mobil North Sea, 1992, Mobil 1993) support hydrocarbon generation in the Forth Approaches Basin. Vincent (2015) estimated that a well drilled in the deepest part of the basin (over $700 \mathrm{~m}$ deeper than 26/08-1) would be gas mature at Firth Coal/Scremerston Formation source rock level. However, the volume of source rock units reaching the maximum depths is likely to have been small.

\subsection{D BASIN MODELLING AND SUMMARY}

3D maturity and migration modelling, integrating $5 \mathrm{~km}$ resolution seismic depth grids (Arsenikos et al., 2015) and the 1D modelled wells for the Scremerston Formation source rock was undertaken by Vincent (2015). Oil and gas generation and expulsion was modelled in Quadrants $42-44$ and southern parts of Quadrant 36 with north-westerly and north-easterly up-dip migration to regional highs (Figure 15). The detail of migration and accumulation modelling was not considered reliable due to the sparse input data and the limited extent and smoothed $5 \mathrm{~km}$ resolution of seismic depth 
grids . Similar migration pathways in Quadrants 41-43 were predicted by Collinson et al. (1995) into up-dip clastic reservoirs.

In summary, basin modelling highlights good quality Visean-Namurian coal and mudstone source rocks beneath Quadrants $41-43$ that are gas mature (Figure 13). This area is modelled as being a hydrocarbon generation centre (kitchen area) in Cenozoic times (Figure 15), in agreement with observed shows and discoveries. Wells that have sampled less deeply buried Carboniferous strata on the margins of the North Dogger Basin or in Quadrant 36/MNSH have the source rock potential for gas and some oil generation, should similar rocks be buried more deeply in the adjacent basins. Basin modelling in the Forth Approaches supports phases of Carboniferous and Mesozoic-Cenozoic oil and possibly gas generation within the basin centre from a coal-bearing Visean-Namurian source rock. As might be expected from the structurally complex arrangement of Carboniferous basins, recent basin modelling and previously published work (e.g. Andrews 2013 onshore examples; in Besly, in press; Catto et al., 2017) emphasise a variability in burial history, maturity and hydrocarbon generation across the area and highlights the need for additional geochemical and maturity input data, as well as detailed local-scale study.

\section{Synthesis: Visean-Namurian petroleum systems and}

\section{petroleum system elements}

Significant variability in Visean-Namurian petroleum system elements and prospectivity can be synthesised by piecing together regional scale seismic, well, sample analysis, petrophysical and basin modelling data and interpretation across and around the MNSH. 


\subsection{SOUTHERN MARGIN OF THE MID NORTH SEA HIGH}

All the elements of a working petroleum system are in place on the southern margin of the MNSH (Quadrants 41 - 44; Figures 14, 15). The petroleum system elements occur within stacked successions proved to be kilometres thick. However, there is much local variability related to the change from a fluvio-deltaic and shallow marine Visean - Namurian 'clastic play' to a deep water and marine 'basinal play' and also differences in Palaeozoic and post-Palaeozoic burial and uplift history. In the northern parts of Quadrants 41-44, some largely gas-prone sections of the Visean-Namurian 'clastic play' are gas mature and with good to excellent source rock quality; others are within oil window maturity levels. In southern parts of Quadrants 41-44, the mudstone-siltstone dominated 'basinal play' is largely gas mature to overmature and may have generated significant hydrocarbons in Carboniferous times, as well as undergoing Cenozoic hydrocarbon generation and expulsion (Figures 13, 14). Multistorey channel sandstones form proved reservoirs, with dip and faulted closures against the base Permian unconformity and Zechstein evaporite seal (Figure 12; e.g. Breagh Field). To ensure the trapping of migrated oil and gas, Cenozoic hydrocarbon generation is likely critical for current preservation of oil and gas accumulations (Figure 14).

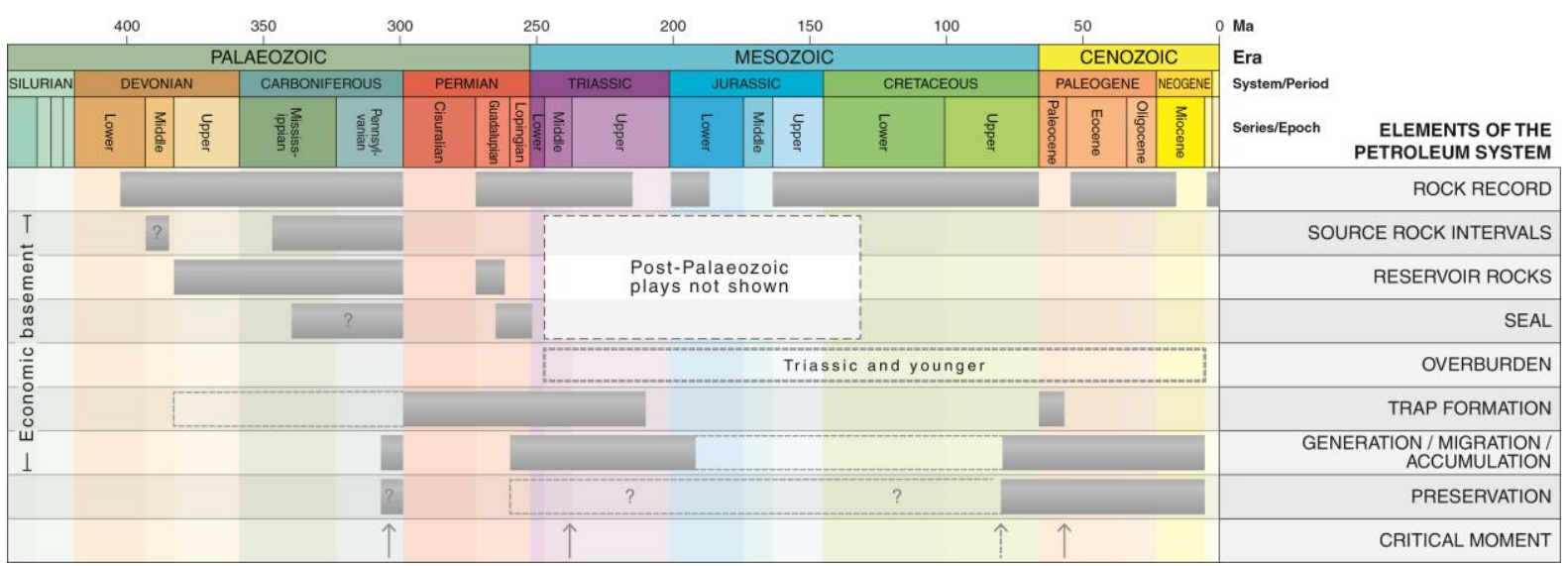

Figure 14 Critical elements summary for the southern margin of the Mid North Sea High. The Mesozoic-Cenozoic timing of generation varies dependent on location, with an Eocene phase of generation widely observed in basin modelling studies. 


\subsection{NORTH DOGGER AND QUADRANT 29 BASINS.}

The North Dogger and Quadrant 29 basins are constrained by limited data, but from those data that exist there are hints of an active Carboniferous petroleum system. Well and seismic interpretations from Arsenikos et al. (2015; in press) concur with previous work (Hay et al., 2005; Milton-Worssell et al., 2010) that a coal-bearing lower Carboniferous succession (Scremerston Formation) can be picked on seismic over much of this area. Most wells were dry but 38/16-1 has weak gas shows, 39/07-1 has poor oil shows and there are Carboniferous-sourced oil shows present in the Permian strata in southern parts of Quadrant 29. Palaeozoic-sourced shows are present in The Netherlands sector, along strike from the North Dogger Basin (e.g. wells A14-01, A15-01 north of the Elbow Spit EBN, 2015a; ter Borgh et al., in press a). Shallow gas and gas chimneys in southern parts of Quadrant 29 may indicate a gas mature Palaeozoic source (Hay et al., 2005) although no supporting data were collected to advance this hypothesis during our study. Wells at the margins of the North Dogger basin prove oil window levels of maturity, good quality coal- and mudstone-bearing source rocks of the Visean-Namurian clastic play, with interbedded or underlying potential sandstone reservoir units. Although lack of data gives low confidence results, basin modelling indicates potential prospectivity if the same gas and oil-prone source rocks are more deeply buried within these basins.

A Zechstein seal is present over much of the area, although it is thin in northern parts of Quadrants $38-39$.

\subsection{MID NORTH SEA HIGH}

Very limited data preclude full interpretation of a potential petroleum system or system elements across much of the Carboniferous 'Mid North Sea High' from southern parts of Quadrant 26 to Quadrant 37. Largely gas-prone Visean-Namurian age source rocks are proved in Quadrant 36 but with oil window maturity levels such that basin modelling does not indicate gas generation in the Yoredale Formation strata at the wells studied. The same source rocks buried more deeply within adjacent basins could offer increased prospectivity. Large areas of southern parts of Quadrants 26 to 
Quadrant 37 lack evidence of a Carboniferous source rock. However, there is the possibility of coal, mudstone or oil-shale intervals deposited in unproved, undrilled, isolated basins between the widely spaced seismic lines examined.

\subsection{FORTH APPROACHES BASIN}

In the Forth Approaches Basin, all the elements of the petroleum system are in place within Carboniferous and Permian strata, and there are multiple potential reservoir opportunities within a stacked system. Along strike onshore in the Midland Valley of Scotland, the Carboniferous petroleum system has previously been exploited (Hallett et al., 1985; Underhill et al., 2008; Monaghan, 2014). Critical to the prospectivity in the Forth Approaches is the volume of source rock present, timing and level of maturation. Hydrocarbon shows in wells 26/07-1 and 26/08-1 are evidence of generation and migration from the poor to excellent quality coal- and mudstone-bearing source rocks of the Firth Coal/Scremerston Formation. Basin modelling indicates oil window levels of maturity in 26/081 at the level of largely gas-prone source rocks. Gas mature intervals may be present in the deepest parts of the basin but the volume of gas mature strata at the Cenozoic critical moment may be limited. If extensive lacustrine oil-shales exist offshore, as they do onshore in the Midland Valley of Scotland (Loftus and Greensmith, 1988; Monaghan, 2014; Parnell, 1988) then an oil-prone play could be prospective, based on current basin modelling. Seismic data quality and spacing are such that there is a risk to accurately mapping basin geometries within the structurally complex Carboniferous basin. 


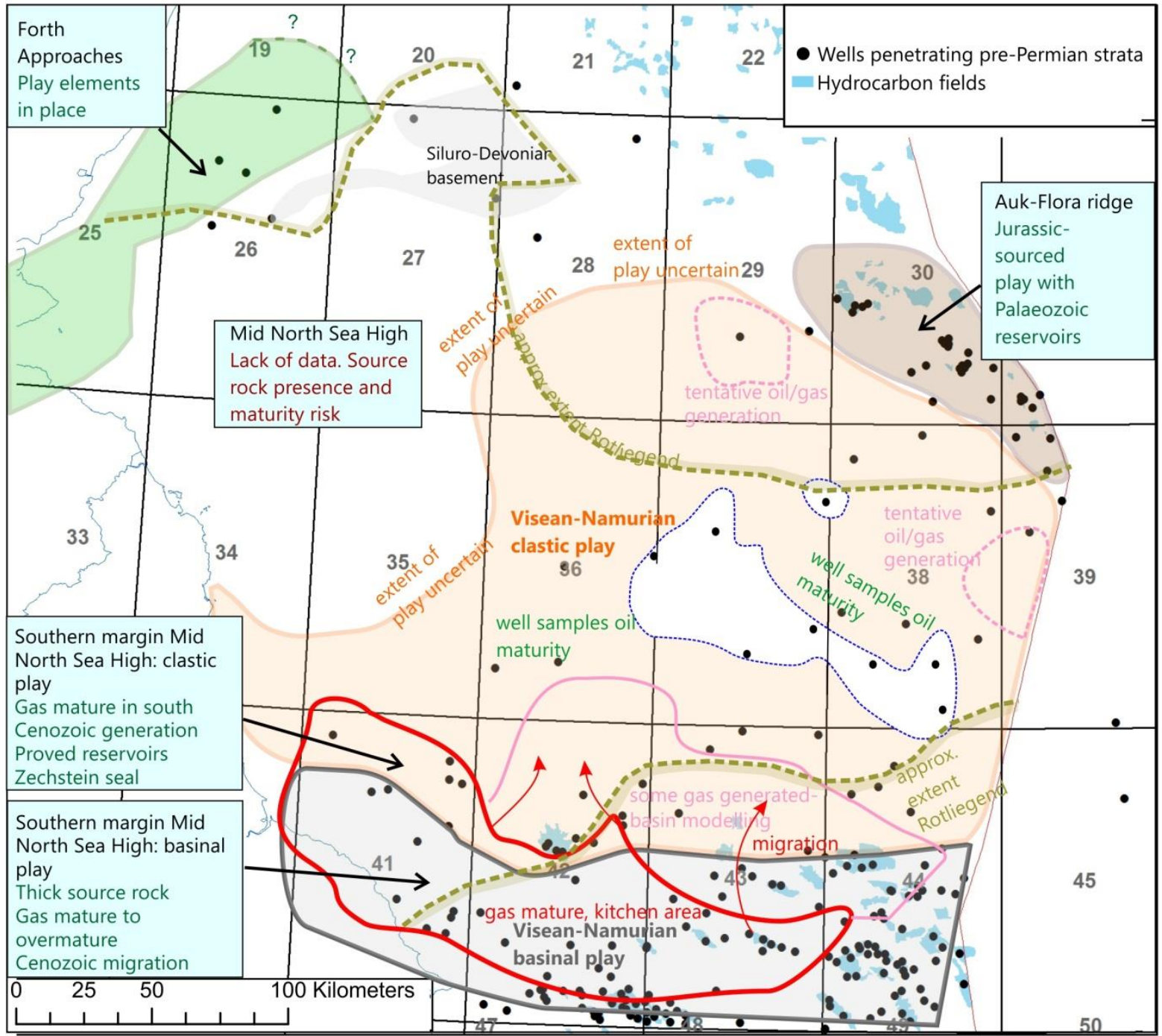

Figure 15 Summary map of Visean-Namurian petroleum systems elements on and around the Mid North Sea High.

In and around the MNSH, most wells penetrating Carboniferous strata have targeted faulted and folded regional highs. However, mudstone source rock quality is likely to be best in basin centres, where maturity is likely to be higher, and fluvial, deltaic and turbiditic channel sandstones are likely to have been focussed into depositional lows. For this reason, detailed evaluation of basin and slope/margin settings with stratigraphic traps could be worthwhile within the Carboniferous petroleum system. 
Detailed, local study is required to understand the Visean-Namurian petroleum system elements further, such as the northward extent of mature source rocks, the extent and quality of Carboniferous and Permian reservoir intervals, and the effectiveness of intra-Carboniferous seals in a potentially stacked play. Since the release of the collated data and reports to Sponsors of the 21CXRM Palaeozoic Project in 2015-2016, upon which this paper is based, exploration activity by a number of companies has added to the growing evidence on the prospectivity of the ViseanNamurian petroleum system and system elements. For example, Cluff Natural Resources (2017) have highlighted a number of Visean-Namurian self-sourcing and self-sealing prospects in Quadrants 41, 42 and 43. The Andromeda and Pegasus discoveries (Quadrant 43) lie west of the Cavendish gas field within stacked Namurian to early Westphalian successions (Walters, 2016). In the south of Quadrant 42, BP (2016) reported that drilling had commenced on a well targeting Namurian sandstones beneath the Ravenspurn Field (block 43/26a). Thus, exploration interest in the ViseanNamurian petroleum system elements has developed.

\section{Discussion and Conclusions}

Evidence has been summarised for prospective Visean-Namurian petroleum systems in basins underlying and surrounding the geographic region of the MNSH in Quadrants $25-44$ of the UKCS. A widespread spatial and temporal extent of oil and gas mature source rock intervals exists within:

- lower Carboniferous (Visean) coals and mudstones of the Scremerston Formation, dominantly fluvio-deltaic and lacustrine with some marine influence, dominantly gas-prone. Gas mature in Quadrant 41 and central-southern parts of Quadrants $42-44$ and oil mature in the Forth Approaches and North Dogger Basin.

- Visean-Namurian (lower-middle Carboniferous) coals and mudstones of the Yoredale and Millstone Grit formations in fluvio-deltaic to marine cycles, gas-prone with oil-prone 
intervals. Gas mature in central part of Quadrant 41 and southern parts of Quadrants 42-43, oil mature across northern parts of Quadrants 41-44, Quadrant 36, 38 and 39.

- Visean-Namurian (lower-middle Carboniferous) mudstones and siltstones of the Cleveland Group, over $1 \mathrm{~km}$ thick, deposited in basinal environments. Gas mature to overmature in southern parts of Quadrants 41-44 and modelled as having generated oil and gas.

Potentially widespread reservoir intervals include channel sandstones within the fluvio-deltaic Visean-Namurian Scremerston, Yoredale and Millstone Grit formations and the laterally extensive, high NTG Fell Sandstone Formation.

There are widespread opportunities for structural (fault/fold/dip) traps utilising a Silverpit mudstone, or Zechstein evaporite seal, as is proved in the Breagh Field. Intraformational Carboniferous seals are documented widely in onshore Carboniferous fields and in some offshore fields. These should be further investigated, particularly in mudstone/siltstone-dominated basinal successions with modelled Carboniferous and recent hydrocarbon generation, along with possibilities for stratigraphic traps.

Multiple, stacked source, reservoir and seal rock intervals are commonly interpreted through the kilometres-thick Carboniferous succession. Within this, several spatially and geologically distinct Carboniferous play systems are described. Visean-Namurian clastic and basinal plays on the southern margin of the MNSH (Quadrants 41-44) are constrained by the most data and have the highest confidence in interpretations.

There are indirect indications (gas chimneys, limited shows, good quality source rocks at the basin margin) of a clastic-dominated Visean-Namurian play present in the seismically mapped North Dogger and Quadrant 29 basins to the north and east of the Dogger granite block (Quadrants 28, 29, 38 , 39). To the north of the MNSH, oil and gas shows demonstrate the Carboniferous clastic petroleum play of the Forth Approaches Basin. 
A substantial set of evidence, much of it previously unpublished, for the Visean-Namurian petroleum system in the Central North Sea is summarised. Placed within the regional context of Visean-Namurian petroleum system elements that extend from the Irish Sea, onshore northerncentral England, and across the North Sea into The Netherlands sector, this synthesis demonstrates a regional understanding of a complex succession with a variable uplift/burial/thermal history and therefore maturation/migration history. Future exploration opportunities are highlighted, with data and evidence used to de-risk aspects of the petroleum system. For example, the distribution of a mature source rock is the main risk in the Visean-Namurian petroleum system. A variety of dominantly gas-prone but also oil-prone source rocks (coals, marine and lacustrine shales) are proved and a gas mature generative area is delineated on the southern margin of the MNSH. We find there is no need to invoke long range migration of Westphalian-sourced gas for the recorded shows, discoveries and fields within Visean and Namurian strata, in agreement with Besly (in press). Further detailed work on the maturation and basin modelling of Visean-Namurian coal and mudstone source rocks is recommended, to shatter the 'founding myth' (Besly, in press) that 'gas comes from Westphalian coals'.

There is clearly potential for the positive play elements that have worked successfully in the Breagh field to be present at other locations to the north of the world-class SNS Carboniferous gas province, extending the life of the mature North Sea province into frontier areas and plays. In addition, new stratigraphic and structural play types requiring intraformational Carboniferous sealing appear worthy of exploration given knowledge of producing fields onshore UK and in the SNS gas basin. Tight gas in the Visean-Namurian basinal play offers another potential opportunity given the maturity and organic richness of this thick succession. A review of current activity suggests exploration is currently underway to further investigate several Visean-Namurian prospects. 


\section{Acknowledgements}

Project sponsors and seismic companies are thanked for data donations and their peer review at Technical Steering Committee meetings. John Collinson and Colin Jones with co-authors Graham Blackbourn and IGI Ltd, along with Peter Dolan are thanked for donation of commercial reports. This work is a synthesis of part of the $21^{\text {st }}$ Century Exploration Roadmap Palaeozoic Project, a jointindustry project funded by 49 sponsoring oil and gas companies DECC/OGA, Oil and Gas UK and BGS/NERC. The work was completed independently by BGS with peer review by industry and OGA. Vanessa Starcher, Margaret Stewart and David Schofield are thanked for BGS review of this paper, along with two external reviewers. This paper is published with the permission of the Executive Director, British Geological Survey (NERC).

\section{References}

Amoco (U.K.) Petroleum LTD. 1967 Final Well Log 38/16- 1. Downloaded from CDA.

ANADRILL, 1990. End of well report. Well 41/14-1. Conoco (UK) Limited. R3021041. Downloaded from CDA.

ANDREwS, I J. 2013. The Carboniferous Bowland Shale gas study: geology and resource estimation. British Geological Survey for Department of Energy and Climate Change, London, UK. https://www.ogauthority.co.uk/explorationproduction/onshore/reports-bowland-shale-gas-study/

Applied Petroleum Technology (UK) Limited, 2012. Appendix 1.2.1. Vitrinite reflectivity and UK fluorescence data. Report produced for Centrica Energy Upstream 2011 and available from BGS Corestore

ARFAI, J. \& LUTZ, R. 2017, online first. 3D basin and petroleum system modelling of the NW German North Sea (Entenschnabel). In: Bowman, M. \& Levell, B. (eds) Petroleum Geology of NW Europe: 50 Years of Learning Proceedings of the 8th Petroleum Geology Conference. https://doi.org/10.1144/PGC8.35

Armstrong, J. P., Smith, J., D'Elia, V. A. A. \& Trueblood, S. P. 1997. The occurrence and correlation of oils and Namurian source rocks in the Liverpool Bay-North Wales area. IN: MEADOWS, N. S., TRUEBLOOD, S. P., HARDMAN, 
M. AND COWAN, G. (EDITORS) Petroleum Geology of the East Irish Sea and Adjacent Areas. Geological Society,London, Special Publications, Vol. 124, 195-211

ARPET, 1967. Well history ARPET 36/13 No. 1. Downloaded from CDA.

Arsenikos, S., Quinn, M.F., Pharaoh, T., Sankey, M And Monaghan, A.A. 2015. Seismic interpretation and generation of key depth structure surfaces within the Devonian and Carboniferous of the Central North Sea, Quadrants 25 - 44 area British Geological Survey Commissioned Report, CR/15/118. 66pp. Available at http://nora.nerc.ac.uk/516758/

Arsenikos S, Quinn M, Kimbell G, Williamson P, Pharaoh T, Monaghan A A, Leslie A G. In press. Structural development of the Devono-Carboniferous plays of the UK North Sea. To Palaeozoic Plays of NW Europe, eds Monaghan A.A, Underhill J.R, Marshall J \& Hewett A. Geological Society of London, Special Publication

BeSLy B M. 1998. Carboniferous. In Petroleum Geology of the North Sea: Basic concepts and recent advances. Glennie K W. (editor) p104-136. Oxford: Blackwell Science Ltd

BESLY, B., 2005. Late Carboniferous redbeds of the UK southern North Sea, viewed in a regional context. In: J. Collinson, D. Evans, D. Holliday and N. Jones (Editors), Carboniferous Hydrocarbon Geology: the southern North Sea and surrounding onshore areas. Yorkshire Geological Society Occasional Publication Volume 7, 225-226.

BESLY, B. In press.. Exploration and development in the Carboniferous of the southern North Sea: a 30 year retrospective . To Palaeozoic Plays of NW Europe, eds Monaghan A A., Underhill J R, Marshall J \& Hewett A. Geological Society of London, Special Publication

Blackbourn Geoconsulting And John Collinson Consulting. 2006. The Occurrence, Petrography and Origin of Quartzitic Sandstones in the Namurian and Lower Westphalian of Quadrants 43 and 44, Southern North Sea. Report.. 216 pages. PDF available from BGS.

BP (2016) Accessed via website January 2017. http://www.bp.com/en/global/corporate/press/press-releases/bp-announcesstart-of-drilling-on-new-carboniferous-prospect-in.html

Breunese J., Anderson J., Brinkman S., Jagosiak P., Karnin W., Karnkowski P., Kombrink H., Messner J., MijnliefF H., Olsen S B., Peryt T., Piske J., Poprawa P., Roelofsen J., Stoker S., Smith N., Swann G., Waksmundzka M. and VeldKamp H. 2010. Appendix 3. In: (editors): Petroleum Geological Atlas of the Southern Permian Basin Area. EAGE Publications b.v. (Houten): 305-314 
BRUCE D R S. AND STEMMERIK L. 2003. Carboniferous. In The Millennium Atlas: petroleum geology of the central and northern North Sea. Evans D., Graham C., Armour A. and Bathurst P. (editors and co-ordinators) p83-89. London: Geological Society of London

Cameron T D J., Crosby A., Balson P S., JefFery D H., Lott G K., Bulat J. And Harrison D J. 1992a. Upper Permian. In United Kingdom offshore regional report: the geology of the southern North Sea. London: HMSO for the British Geological Survey: 43-54

Cameron., Crosby A., Balson P S., Jeffery D H., Lott G K., Bulat J. and Harrison D J. 1992B. Lower Permian. In United Kingdom offshore regional report: the geology of the southern North Sea. London: HMSO for the British Geological Survey: $38-42$

Cameron, T D J. 1993a. 5. Carboniferous and Devonian of the southern North Sea. In: R. Knox and W. Cordey (Editors), Lithostratigraphical Nomenclature of the UK North Sea. London: HMSO for the British Geological Survey

Cameron, T D J. 1993b. 4. Triassic, Permian and Pre-Permian (Central and Northern North Sea) . In: R. Knox and W. Cordey (Editors), Lithostratigraphical Nomenclature of the UK North Sea. London: HMSO for the British Geological Survey

CAMERon D., MunNS J. \& STOKER S. 2005. Remaining hydrocarbon exploration potential of the Carboniferous fairway. In: J. Collinson, D. Evans, D. Holliday and N. Jones (Editors), Carboniferous Hydrocarbon Geology: the southern North Sea and surrounding onshore areas. Yorkshire Geological Society Occasional Publication Volume 7, 209-224.

Catto, R., Taggart, S. And Poole, G. 2017. Bowman, M. \& Levell, B. (eds) Petroleum Geology of NW Europe: 50 Years of Learning - Proceedings of the 8th Petroleum Geology Conference, https://doi.org/10.1144/PGC8.39

ChuRCh K D. \& GAwTHORPe R L. 1994. High resolution sequence stratigraphy of the late Namurian in the Widmerpool Gulf (East Midlands, UK). Marine and Petroleum Geology, 11, 528-544

Cluff NAtural ResourCes. 2017 Website ACCESSED JaN 2017. HTTP://WwW.CLUfFNATURALRESOURCES.COM/ASSETS/OILGAS/SOUTH-NORTH-SEA/ AND DETAILED PAGES ON P2248 AND P2252

COLLINSON J, JONES C. AND IGI LTD. 1995. Source rock potential of the sub-Westphalian Carboniferous of the Southern North Sea. Report and Appendix 235 pages. 
Collinson, J., 2005. Dinantian and Namurian depositional systems in the southern North Sea. In: J. Collinson, D. Evans, D. Holliday and N. Jones (Editors), Carboniferous Hydrocarbon Geology: the southern North Sea and surrounding onshore areas. Yorkshire Geological Society Occasional Publication Volume 7, 35-56.

Collinson, J. AND Jones, C. 1997. Reservoir distribution and controls in the Dinantian and Lower Namurian of Quadrants 41, 42 and 43, Southern North Sea. Report 97pp and 3 Appendices.

Copestake, P, Dunford, G, Billings, A, Wright, T And CARr, A D, 2009. Geophysical \& Geological Evaluation of Blocks 29/20b, 29/20c, 29/19a, 29/24 \& 29/25 (Licences P1318, P1319), UK North Sea; Part 1. October 2009. Merlin Energy Resources Ltd, Dunford Exploration, Hornet Geoconsulting Ltd and Advanced Geochemical Systems for PA Resources. Confidential report donated for 21CXRM Palaeozoic Project.

ConOCoPHILlIPS 2011 Licence Relinquishement Report UKCS Licences: P.1432 ; P. 1586 ; P.1587 Blocks 29/27, 29/28, 29/29, 37/3 and 37/4; P.1586 (Block 29/23) and P. 1587 (Block 29/30)) Downloaded from https://itportal.decc.gov.uk/web_files/relinqs/p1432-p1586-p1587.pdf

Conway A M. \& Valvatne C. 2003. The Boulton Field, Block 44/21a, UK North Sea. In In Gluyas J G. and Hichens H M. (editors): United Kingdom Oil and Gas Fields, Commemorative Millennium Volume. London: Geological Society Memoir, $20,671-680$.

DEA Group 2015 The Breagh offshore gas field. [Online] Available from: http://www.dea-group.com/en/projects/breagh [Accessed: November 2015]

DECC 2013 The hydrocarbon prospectivity of Britain's onshore basins. Downloaded from https://www.gov.uk/government/uploads/system/uploads/attachment_data/file/367284/UK_onshore_2013.pdf [Accessed Feb $\underline{2017]}$

Dolan P \& Associates. 1994. New UKCS Gas Plays. Coals as Sources and Reservoirs. Commercial report and 3 Appendices.

EBN 2015a Poster from EAGE downloaded from the website https://www.ebn.nl/wpcontent/uploads/2014/11/Poster4_EBN_EAGE2015_Dinant.pdf [Accessed 14/12/15]

EBN 2015b Poster from EAGE downloaded from the website https://www.ebn.nl/wpcontent/uploads/2014/11/Poster6_EBN_EAGE2015_TectD.pdf [Accessed 14/12/15]

Farris M., Allen M. And King C. 2012 Central North Sea Palaeozoic, Sub-Salt Prospectivity, produced for Shell U.K. Limited. Confidential report donated for 21CXRM Palaeozoic Project. 
Fraser A J. \& GAWTHORPE R L. 2003. An atlas of Carboniferous basin evolution in northern England. Geological Society of London, Memoir 28.

Gast, R E., Dusar, M., Breitkreuz, C., Gaupp, R., Schneider, J W., Stemmerik, L., Geluk, M C., Geisler, M., Kiersnowski, H.,Glennie, K W., KABEL, S. \& Jones, N S., 2010. Rotliegend. In: Doornenbal, J C. and Stevenson, A G. (editors): Petroleum Geological Atlas of the Southern Permian Basin Area. EAGE Publications b.v. (Houten): 101-121.

GENT, C M A, 2015. Total organic carbon calculation using geophysical logs for 31 wells across the Palaeozoic of the Central North Sea. British Geological Survey Commissioned Report, CR/15/121. 74pp. Available at http://nora.nerc.ac.uk/516744/

Gerling P., Geluk M C., LoKhURST A., LotT G.K. \& Nicolson R A. 1999. NW European Gas Atlas - new implications for the Carboniferous gas plays in the western part of the Southern Permian Basin. In Petroleum Geology of northwest Europe; proceedings of the $5^{\text {th }}$ conference. A J Fleet and S A R Boldy (eds), 799-808. London: Geological Society.

Glenister, I, Fryberger, S, Pugh, J And Price, S. 2001. Forth Approaches 26/4-A Shell/Esso Prospect Description. Report ER01011. Downloaded from CDA.

Glenister, I, Milner, S, Jones, B And Elsinger, B. 2002. Forth Approaches 26/4-1 Well resume. Shell U.K. Limited. Report ER02008 Downloaded from CDA.

Glennie, K., Highman, J. And Stemmerik, L., 2003. Permian. In: D. Evans, C. Graham, A. Armour and P. Bathurst (Editors). The Millennium Atlas: Petroleum Geology of the Central and Northern North Sea. The Geological Society of London, pp. 8-1: 8-44

GRANBY ENTERPRISES AND TGS-NOPEC. 2010. Relinquishment report P1315 Blocks 26/4a, 26/5, 26/9, 26/10a, 27/1a, 27/6a. Downloaded from https://itportal.decc.gov.uk/web_files/relinqs/p1315.pdf

Hallett, D., Durant, G.P. \& Farrow, G.E. 1985. Oil exploration and production in Scotland. Scottish Journal of Geology 21: $547-570$.

HAMPSON G J. 1997. A sequence stratigraphic model for deposition of the Lower Kinderscout Delta, an Upper Carboniferous turbidite fronted delta. Proceedings of the Yorkshire Geological Society, 51, 273-296.

HAMPSON G J., ElliotT T \& DAVIES S J. 1997 The application of sequence stratigraphy to Upper Carboniferous fluviodeltaic strata of the onshore UK and Ireland: implications for the southern North Sea. Journal of the Geological Society of London, 154, 719-733. 
HANNIS, S. 2015. Reservoir evaluation of 12 wells in the Devonian - Carboniferous of the Central North Sea: Petrophysical interpretations of clay volume, porosity and permeability estimations. British Geological Survey Commissioned Report, CR/15/120. 55pp. Available at http://nora.nerc.ac.uk/516763/

Hay S., Jones C M., BARKer, F. AND HE Z. 2005 Exploration of Unproven Plays; Mid North Sea High. Produced for EUPP Mid North Sea High Consortium, Report.

HodGe, T. 2003. The Saltfleetby Field, block L 47/16, licence PEDL 005, onshore UK. In: United Kingdom oil and gas fields commemorative Millennium Volume. Memoirs of the Geological Society of London, 20, 911-919

JONES, N.S. 2007. The Scremerston Formation: results of a sedimentological study of onshore outcrop sections and offshore Well 42/13-2. British Geological Survey Commissioned Report, CR/07/101. 70pp

Jones C M. \& ChISHOLM J I. 1997. The Roaches and Ashover Grits: sequence stratigraphic interpretation of a `turbiditefronted delta' system, Geological Journal, 32, 45-68.

KAYE M N D. 1995 Well 41/10-1 Source Rock Evaluation Geochemistry Report, prepared for Marathon Oil UK Ltd by OceanGrove Geoscience Limited. Downloaded from CDA.

KAYE, M N D, 1996. Well 42/10b-2 source rock evaluation geochemistry report. Ocean Grove Geoscience Limited. Report prepared for Mobil North Sea Limited. Project GC960001. Downloaded from CDA.

Kearsey, T, Ellen, R, Millward, D. And Monaghan, A.A. 2015. Devonian and Carboniferous stratigraphical correlation and interpretation in the Central North Sea, Quadrants 25 - 44. British Geological Survey Commissioned Report, CR/15/117. 80pp. Available at http://nora.nerc.ac.uk/516755/

Kearsey T I, Millward D, Ellen R, Whitbread K, Monaghan A A. In press. Unified stratigraphy of Carboniferous petroleum system elements from the Outer Moray Firth to the Silverpit basin, North Sea, UK. To Palaeozoic Plays of NW Europe, eds Monaghan A A, Underhill J R, Marshall J \& Hewett A. Geological Society of London, Special Publication

Kimbell, G S, Williamson, J P. 2015. A gravity interpretation of the Central North Sea. British Geological Survey Commissioned Report, CR/15/119. 75pp. Available at http://nora.nerc.ac.uk/516759/

Kombrink, H., Besly, B M., Collinson, J D., Den Hartog Jager, D G., Drozdzewski, G., Dusar, M., Hoth, P., Pagnier, H J M.,Stemmerik, L., Waksmundzka, M I. \& Wrede, V., 2010. Carboniferous. In: Doornenbal, J C. and Stevenson, A G. (editors):Petroleum Geological Atlas of the Southern Permian Basin Area. EAGE Publications b.v. (Houten): 81-99. 
Loftus, G.W.F. \& GREenSMITH, J.T. 1988. The lacustrine Burdiehouse Limestone Formation —a key to the deposition of the Dinantian Oil Shales of Scotland. In: Fleet, A.J., Kelts, K. \& Talbot, M.R. (eds) Lacustrine Petroleum Source Rock. Geological Society, London, Special Publication, 40, 219-234

MAYNARD J R \& DunAy R E. 1999. Reservoirs of the Dinantian (Lower Carboniferous) play of the Southern North Sea. In Petroleum Geology of northwest Europe; proceedings of the $5^{\text {th }}$ conference. A J Fleet and S A R Boldy (eds), 729-45. London: Geological Society.

Milton-Worssell R., Smith K., McGrandle A., Watson J \& Cameron D. 2010. In (eds) Vining, B.A. \& Pickering, S. C. The search for a Carboniferous petroleum system beneath the Central North Sea. Petroleum Geology: From Mature Basins to New Frontiers - Proceedings of the 7th Petroleum Geology Conference, 57-75. DOI: 10.1144/0070057

Mobil North Sea Ltd 1992 Final Well Report 26/8-1 R3251199 for Mobil North Sea Ltd . Downloaded from CDA. Mobil NoRTh SEa LTD 1993 Geological Final Well Report Well 26/8-1 R3251200 for Mobil North Sea Ltd. Downloaded from CDA.

Monaghan A A, S. Arsenikos, E Callaghan, R Ellen, C Gent, S Hannis, A Henderson, G Leslie, K Johnson, M Kassyk, T Kearsey, A Kim, G Kimbell, M Quinn, W McLean, D Millward, T Pharaoh, M Sankey, N Smith, C Uguna, C Vane, C Vincent, P Williamson. 2015. Palaeozoic Petroleum Systems of the Central North Sea/Mid North Sea High. British Geological Survey Commissioned Report, CR/15/124. 105pp. Available at http://nora.nerc.ac.uk/516766/

Monaghan, A.A. 2014. The Carboniferous shales of the Midland Valley of Scotland: geology and resource estimation. British Geological Survey for Department of Energy and Climate Change, London, UK. https://www.ogauthority.co.uk/exploration-production/onshore/reports-bgs-midland-valley-of-scotland-shale/

O’Mara, P T., Merryweather M, Stockwell, M \& Bowler M. 2003. The Trent Gas Field, Block 43/24a, UK North Sea. In Gluyas J G. and Hichens H M. (editors): United Kingdom Oil and Gas Fields, Commemorative Millennium Volume. London: Geological Society Memoir, 20, 835-849.

PALEOCHEM LiMITED, 1984. Petroleum geochemistry report prepared for Burmah Oil Exploration Ltd. Well 38/18-1 R3282394, downloaded from CDA.

PA ResOuRCES 2011. Relinquishment Report License P1318 23rd Round Promote UKCS Blocks 29/19a, 29/20b, 29/24, 29/25. Downloaded from https://itportal.decc.gov.uk/web_files/relinqs/p1318.pdf 
PARNELL, J. 1988. Lacustrine petroleum source rocks in the Dinantian Oil Shale Group, Scotland: a review. In: Fleet, A.J., Kelts, K. \& Talbot, M.R. (eds) Lacustrine Petroleum Source Rocks. Geological Society Special Publication, 40, 235-246.

PARSONS T. 2015. New plays in a mature basin: a review of the Lower Carboniferous on the southern margin of the MidNorth Sea High. Abstract and presentation at Petroleum Geology of Northwest Europe conference, 28-30 September 2015, London.

Passey. Q.R, Creaney.S., Kulla. J. B., MoretTI. F.J. And Stroud. J.D. 1990, A Practical Model for Organic Richness from Porosity and Resistivity Logs. AAPG Bulletin, 74, 1777-1794pp

PATRUNO. S., ReID. W., JACKSON. C. A-L. AND DAVIES. C. 2017. New insights into the unexploited reservoir potential of the Mid North Sea High (UKCS quadrants 35-38 and 41-43): a newly described intra-Zechstein sulphate-carbonate platform complex. In Bowman, M. \& Levell, B. (eds) Petroleum Geology of NW Europe: 50 Years of Learning. Geological Society, London, Petroleum Geology Conference series, 8, 13 June 2017, https://doi.org/10.1144/PGC8.9

Peryt T M., Geluk M., Mathiesen A., Paul J. And Smith K. 2010. Zechstein. In: Doornenbal, J C. and Stevenson, A G. (editors): Petroleum Geological Atlas of the Southern Permian Basin Area. EAGE Publications b.v. (Houten): 123-148

PESGB magazine, December 2016 issue, page 50. Available online at https://issuu.com/pesgb64/docs/december_2016

Pharaoh, T C, Vincent, C J, Bentham, M S, Hulbert, A G, Waters, C N, And Smith, N J. 2011. Structure and evolution of the East Midlands region of the Pennine Basin. Subsurface memoir of the British Geological Survey.

PitTiOn J L. 1981 Geochemical Study of Carboniferous and Permian in Scarborough Area, 41/20-1, 44/2-1, 44/21-1 Wells by Total Group Laboratories. Downloaded from CDA.

Pletsch, T., Appel, J., Botor, D., Clayton, C.J., Duin, E J T., Faber, E., Gorecki, W., Kombrink, H., Kosakowski, P., Kuper, G.,Kus, J., Lutz, R., Mathiesen, A., Ostertag-Henning, C., Papiernek, B. \& Van Bergen, F., 2010. Petroleum generation and migration. In: Doornenbal, J C. and Stevenson, A G. (editors): Petroleum Geological Atlas of the Southern Permian Basin Area. EAGE Publications b.v. (Houten): 225-253.

Premier Oil 2008. Relinquishment Report P1229 License Blocks 42/10 and 42/15 Parts 1 and 2 Downloaded from https://itportal.decc.gov.uk/web_files/relinqs/p1229-p1.pdf 
REDWOOd CoReX, 1989. Conventional core analysis study for well 43/2- 1 prepared for Amoco (UK) Exploration Company. Downloaded from CDA.

ROC OIL 2005. Errington 1 Well results and formation evaluation. Onshore UK Northumberland Project Area PEDL028.

Rodriguez K, Wrigley R, Hodgson N \& Nicolls H. 2014. Southern North Sea. Unexplored multi-level exploration potential revealed. First Break, 32, 107-113

RWE DEA 2011a. Relinquishment report Licence Number: P1524 42/2b, 42/3, 42/4. Downloaded from https://itportal.decc.gov.uk/web_files/relinqs/p1524.pdf

RWE DEA 2011b Relinquishment report Licence Number: P1525 42/18. Downloaded from https://itportal.decc.gov.uk/web files/relinqs/p1525.pdf

SAUER M J. 1992 Geochemical Evaluation of the 43/21-2 Well, Southern North Sea Gas Basin, Prepared for AGIP (UK) Limited by GeoChem Group Limited. Downloaded from CDA.

SAUER M J. 1993 Geochemical Evaluation of the Carboniferous Sediments from the 43/15b-3A Well, prepared for Conoco UK Limited by GeoChem Group Limited. Downloaded from CDA.

Schroot B. M., v.Bergen F., Abbink O. A., David P., v.Eijs R, Veld H. 2006. Hydrocarbon potential of the PreWestphalian in the Netherlands on- and offshore - report of the Petroplay project. TNO report, NITG 05-155-C. Downloaded from the TNO website.

Symonds R., Lippman R., Mueller B. ANd Конок A. 2015. Yoredale Sandstone Architecture in the Breagh Field (UK SNS). Presentation for Sedimentology of Paralic Reservoirs: Recent Advances and their Applications. Geological Society Conference May 2015

Symonds R. 2015 The Breagh Field - A New Frontier in the Backyard. Presentation for Pitfalls, Peaks and Progress conference, Feb 2015.

TAGGART S. 2015. New opportunities on the northern feather-edge play of the Silverpit Basin: sedimentology and facies distribution of the Permian Lower Leman and Carboniferous Ketch Formations, Cygnus Field, Southern North Sea. Abstract and presentation at Petroleum Geology of Northwest Europe conference, 28-30 September 2015, London 
TER Borgh, M M., Eikelenboom, W. And JaArsma, B. In pressa Hydrocarbon potential of the Visean and Namurian in the northern Dutch offshore. To Palaeozoic Plays of NW Europe, eds Monaghan A.A, Underhill J.R, Marshall J \& Hewett A. Geological Society of London, Special Publication

TER Borgh, M M., JaARsma, B. AnD RosendaAl E.A. In pressb A structural framework for the Mid North Sea area, Palaeozoic to present To Palaeozoic Plays of NW Europe, eds Monaghan A.A, Underhill J.R., Marshall J \& Hewett A. Geological Society of London, Special Publication

The Geochem Group, 1988. Geochemical evaluation of the Carboniferous section of the GC(E) Well 43/17-2. December 1988. Prepared for Gas Council (Exploration) Limited. Ref MS/JB16/5146. Downloaded from CDA.

TurNER, B.R., Younger, P.L., \& FordHAM, C.E. 1993. Fell Sandstone Group lithostratigraphy southwest of Berwick-UponTweed: Implications for the regional development of the Fell Sandstone. Proceedings of the Yorkshire Geological Society, 49, 269- 281.

UNDERHILL J. R. 2003. The tectonic and stratigraphic framework of the United Kingdom's oil and gas fields. In Gluyas J G. and Hichens H M. (editors): United Kingdom Oil and Gas Fields, Commemorative Millennium Volume. London: Geological Society Memoir, 20, 17-59

Underhill, J.R., Monaghan, A.A. \& Browne, M.A.E. 2008. Controls on structural styles, basin development and petroleum prospectivity in the Midland Valley of Scotland. Journal of Marine and Petroleum Geology 25: 1000-1022

Walters S. 2016. The Pegasus field: A new Carboniferous gas discovery in the mature Southern North Sea basin. PESGB Lecture September 2016, abstract accessed Jan 2016 at http://www.pesgb.org.uk/events/event-281/

Vane, C H, Uguna, C, Kim A W.. Johnson, K, Monaghan A.A. 2015. Organic Geochemistry of Palaeozoic Source Rocks, Central North Sea (CNS). British Geological Survey Commissoned Report, CR/15/132. 95pp. Available at http://nora.nerc.ac.uk/516765/

VINCENT, C J. 2015. Maturity modelling of selected wells in the Central North Sea. British Geological Survey Commissioned Report CR/15/122. 184pp. Available at http://nora.nerc.ac.uk/516764/

Wood I. 2014. UKCS Maximising Economic Recovery Review: Final Report ‘The Wood Review’ Accessed Dec 2016 from https://www.gov.uk/government/uploads/system/uploads/attachment_data/file/471452/UKCS_Maximising_Recovery_Revie w FINAL 72pp locked.pdf 
Footnote: BGS reports and 21CXRM Palaeozoic datasets can be downloaded from

http://www.bgs.ac.uk/research/energy/petroleumGeoscience/explorationRoadmap.html, or from http://nora.nerc.ac.uk/

CDA reports can be downloaded from https://www.ukoilandgasdata.com 